\title{
Shareholders' control rights, family ownership and the firm's leverage decisions
}

\author{
Qazi Awais Amin ${ }^{\mathrm{a}, *}$, Jia Liu ${ }^{\mathrm{b}}$ \\ ${ }^{a}$ Finance, School of Economics, Finance \& Accounting, Coventry University, CV1 5ED, UK \\ ${ }^{\mathrm{b}}$ Finance, Business School, University of Portsmouth, PO1 3DE, UK
}

\section{A R T I C L E I N F O}

\section{Keywords:}

Ownership concentration

Control rights

Cash flow rights

Leverage

Family ownership

Agency theory

JEL classification:

G31

G32

G34

L21

\begin{abstract}
A B S T R A C T
We investigate the association between controlling shareholders' ownership (CS_Own) and firms' leverage decisions in the Singaporean context. We examine whether the impact of ownership concentration on leverage differs across excess and lower control. We report that shareholders with excess control prefer leverage financing for an optimal capital structure and focus on value maximisation rather using leverage as a tool of minority shareholders' expropriation. Our analysis shows that firms capital structure significantly influences by the coalition of shareholders particularly decisions about leverage financing in addition to the firms' specific characteristics and institutional arrangements. Our empirical evidence shows that controlling shareholders with a lower fraction of equity are more concerned about limited holding thus prefer leverage over equity financing to inflate their equity stake to protect them from the potential takeovers and mergers. We report that capital structure decisions in Singapore are linked with the trade-off between the controlling shareholders' target of mitigating firm risk and their non-dilution entrenchment needs. Further, we found an inverted U-shaped association between control ownership and leverage financing. In terms of moderating effect of family-controlled ownership, our findings exhibit that leverage financing is less pronounced for family firms in Singapore due to the under-diversified investment portfolio.
\end{abstract}

\section{Introduction}

Historically, the empirical literature established the significance of leverage in mitigating agency conflict. The innate agency conflict is between the controlling shareholders and the external investors which influence firms' leverage decisions (Chee, Hooy, \& Ooi, 2016). These agency issues potentially affect the firm's financial strategy, particularly decision about leverage. The leverage financing help to mitigate Type II agency conflict as the controlling shareholders are relatively more flexible in adjusting leverage ratio than equity share capital (de La Bruslerie \& Latrous, 2012).

The shareholders with higher controlling rights tend to face a tradeoff between obtaining leverage financing and diluting their control over the board decision making (Boateng \& Huang, 2017). The leverage financing offers a counter measure to this dilemma while it is not possible by injecting external equity. The predominant research documents that the controlling shareholders tend to manipulate leverage as a channel to place financial resources at their disposal to facilitate tunnelling exercise (Casado, Burkert, Davila, \& Oyon, 2016; Paligorova \& $\mathrm{Xu}, 2012$ ). Therefore, it's not surprising that several studies reported the role of effective CG in curbing the expropriation of minority shareholders.

Importantly, only a few studies have examined the impact of controlling shareholders' ownership (CS_Own) on leverage financing. For example, Abdullah and Pok (2015) and Boubaker (2008) report a positive association between control ownership and leverage. While Santos, Moreira, and Vieira (2014) examine a sample of 12 Western European firms and report a negative relationship between ownership concentration and firms' leverage. Moreover, Nielsen (2006) who, among others, report a trade-off between the higher level of leverage and weak shareholding. A few other studies have estimated a U-shaped non-linear association between ownership structure and firms' leverage (see, for example, Agca \& Mansi, 2008; Brailsford, Oliver, \& Pua, 2002; Lo, Ting, \& Yang, 2016).

Importantly, the limited literature on the association between controlling shareholders' ownership and leverage is quite heterogeneous. For example, in the US context, Crutchley, Jensen, Jahera Jr., and Raymond (1999) and Jensen, Solberg, and Zorn (1992) report that controlling shareholders tend to prefer low leverage financing and dividend payments. Contrary to the US context, the controlling

\footnotetext{
* Corresponding author at: Finance, The Business School, Coventry University, Gosford Street, Coventry CV1 5ED, UK.

E-mail addresses: qazi.amin@coventry.ac.uk (Q.A. Amin), jia.liu@port.ac.uk (J. Liu).
} 
shareholders of other developed countries may collude for their personal benefits to expropriate minority shareholders' interest. (Dyck \& Zingales, 2004; Faccio \& Lang, 2002; La Porta, Lopez-de-Silanes, \& Shleifer, 1999).

We contribute to the literature by examining the association between controlling shareholders' ownership (CS_Own) and the firms' leverage decisions in the Singaporean context. In particular, we investigate the impact of controlling shareholders' ownership on leverage financing across excess control (majority controlling shareholders) and lower control (controlling shareholders with a lower fraction of equity). We ascertain whether shareholders with an excess controlling stake prefer leverage for value maximisation or: alternatively, use as a tool of minority shareholders' expropriation. Theoretically, we link our econometric model with the context of Type II agency conflict as it arises between excess and lower control. In this regard, we conjecture that the association between controlling shareholders and leverage is presumably changed in accordance with the equity stake of controlling shareholders' due to the 'incentive' and 'entrenchment' effect. We postulate that excess and lower control ownership may exhibit distinct financing behaviour towards leverage financing due to the difference in their privileges and investment priorities. To our knowledge, no prior study has examined the controlling shareholders' ownership and leverage financing across excess and lower control.

Given the prevalence of higher level of concentrated ownership in the Singaporean market, we expect that the control ownership-leverage relationship leads to the 'expropriation effect'. Although Singapore is an emerging market, its strong legal and institutional context is largely comparable with the developed market (Nguyen, Locke, \& Reddy, 2015). Singapore holds several traits of developed economies e.g., the strong legal and institutional settings, the effectiveness of the rule of law and adequate investors' protection which enhance the efficacy of CG in curbing the expropriation of minority shareholders thus support the likelihood of monitoring/incentive effect. The likelihood of both opposing effects of control ownership such as 'expropriation effect' and monitoring/incentive effect lead to the inverted-U shape association. We, therefore, further investigate whether controlling shareholders' ownership and firms' leverage nexus is multifaceted and lead to an inverted-U shape association in Singapore.

It is well documented that the monitoring of professional managers becomes challenging particularly for the larger firms due to the deviation between cash flow rights and control rights (De Miguel, Pindado, \& De la Torre, 2004). Therefore, the non-dilution motive for leverage is more likely to be strengthened when there is a separation of control and ownership rights. The deviation between the cash flow rights and control rights is common in controlled firms particularly in Western European and Eastern Asian countries (Claessens, Djankov, \& Lang, 2000). The Singaporean context is recognized as a market with a higher level of ownership concentration (Claessens et al., 2000; Nguyen et al., 2015). We, therefore, further investigate the impact of the divergence between cash flow rights and control rights on firms' leverage financing in the Singaporean context.

The family-controlled firms considered as controlled ownership based on their distinct characteristics. Most of the family firms prefer leverage by considering it as non-dilutive security (Barth, Gulbrandsen, \& Schonea, 2005). The family-controlled firms are more likely to be risk-averse and not prefer external borrowing despite the significance of leverage in a capital structure setting (Wiwattanakantang, 1999). Like other emerging markets, the Singaporean model of control ownership develops mainly through family control, state-owned ownership, pyramidal structure and cross holding (La Porta et al., 1999; Nguyen et al., 2015).

So far, no prior study explores family ownership in the Singaporean context although family firms greatly contribute to the Singapore economic development owing to the strong legal setting, adoption of extensive disclosure reporting standards and protection of the minority shareholders rights. We thus test the moderating role of the family- controlled firm on the relationship between controlling shareholders' ownership and leverage financing.

Importantly, the Singaporean context is discussed in a very few cross countries studies such as (Claessens et al., 2000; Hanazaki \& Liu, 2007; La Porta et al., 1999) which unable to provide a definitive understanding of Singaporean context. Therefore, the present study is important to understand the unique environment of Singapore which differs from most emerging economies in terms of both institutional efficiency and regulatory enforcement yet have other features in common with emerging markets (Demirbag and Yaprak, 2015). In contrast to other emerging economies, the Singaporean market hold several characteristics of developed markets in terms of its well-organized capital market, strong protection to minority shareholders and the national governance quality. To this end, we conduct a detailed analysis of governance attributes and capital structure to investigate whether the control ownership-leverage nexus in Singapore takes place on the line of other emerging economies, or it's context-specific.

Our core findings reveal that controlling shareholders with an excess controlling stake do less rely on leverage financing to minimize the likelihood of default risk. Our evidence shows that controlling shareholders of the Singaporean market tend to use leverage financing for an optimal capital structure and focus on value maximisation rather using leverage as a tool of minority shareholders' expropriation. In addition, we report that controlling shareholders with a lower fraction of equity are more concerned about limited holding thus prefer leverage over equity financing to inflate their equity stake to protect them from the potential takeovers and mergers. Another noteworthy finding of this study reflecting that unlike other emerging markets, the strong disclosure-based environment and efficient monitoring mechanisms in Singapore effectively protect minority' interests, thus separation of ownership and control has no significant impact on leverage financing.

Further, our empirical evidence shows that controlling shareholders first increase the leverage financing to maintain an optimal capital structure indicating 'active monitoring effect' and at a certain threshold, prefer to reduce the leverage level reflecting the 'risk reduction/incentive effect' leading to an inverted U-shaped relationship between control ownership and leverage. Finally, our findings show a negative interaction effect of family-controlled firms suggesting that family controlling shareholders are more averse towards the higher level of leverage due to the risk of financial distress and bankruptcy and as a result of having poorly and under-diversified leadership portfolio.

Our empirical evidence shows that the shareholders with a lower controlling stake in Singapore prefer leverage over equity financing to inflate their equity stake. This reflects that regardless of the disclosurebased environment and strong governance arrangements in Singapore, minority shareholders are concerned about limited holding. Our findings highlight the need for the CG regulator to specifically reconsider the role of minority shareholders regarding involvement in the board key decision making particularly in capital structure decisions. The remainder of the paper is organized as follows. Next section describes the institutional background of the Singaporean market. Section 3 discusses the underlying theory and develops testable hypotheses. Section 4 describes our data and sample selection procedures and explain the measurement of variables. Section 5 and 6 presents our empirical modelling and results respectively and finally, section 7 presents the conclusion and implication of the study.

\section{Institutional background}

The regulations and the disclosure standards of the Singaporean market fall under the domain of more than one institution, an example being the Securities Industry Council, Monetary Authority of Singapore and the Registrar of Companies and Commercial Affairs Department. These departments are well integrated with each other regarding the scrutiny of the standards and the enforcement of regulations which maintain a higher level of governance transparency. 
Contrary to the traditional dynamics of emerging markets, Singapore is recognized as a market with a strong rule of law; yet the nature of the Singaporean regulatory state does not make it a strictly market economy. In addition, the market-based financial system, welldeveloped capital market and the national governance quality of Singapore makes it the most efficient setting across the Asian region (Heugens, Van Essen, \& Van Oosterhout, 2009; Nguyen et al., 2015). In contrast to other emerging markets, the judicial environment of Singapore provides strong protection for minority shareholders under the law: indeed, it is regularly ranked among the highest average country scores for corporate governance (CG) quality across Asia (Chuanrommanee \& Swierczek, 2007; CLSA, 2010, 2012).

The CG framework of Singapore is recognized as a disclosure-based mechanism which accentuates extensive disclosure reporting and efficient monitoring which in turn strengthen a strong corporate culture. Importantly, the institutional setting and governance structure in Singapore differs from most of the Asian and Continental European firms on several counts. For example, the Singaporean market follows the Anglo-American model of CG which accentuate the board independence and effectiveness of board committees. In addition, Singaporean CG is supported by the principle-based approach that primarily adopted from Western jurisdictions (Nguyen et al., 2015).

The equity market of Singapore is tightly held among government, multinationals, regional corporations, large business groups, takeovers and entrepreneurial families. Further, to make the ownership more accountable, the companies act is specifically amended which restrict local and international firms in Singapore to maintain the publicly available data regarding the information of beneficial owners. Moreover, shareholders who control voting rights through other person/firms or other controlling mechanisms such as pyramiding, cross holdings and business groups also required to disclose relevant information. This is supplemented by the Singapore code of takeovers, mergers and quasi-legislative enactments namely 'SGX listing manual. Given the distinct characteristics, the Singapore corporate sector provides an interesting experimental setting to enhance the conceptual understanding of the relationship between controlling shareholders' ownership and the firm leverage decisions.

\section{Literature review and hypothesis development}

Since the seminal research of Modigliani and Miller (1958), several studies focus on firms' internal characteristics and external dynamics which impact capital structure decisions (De Jong, Rezaul, \& Nguyen, 2008; Rajan \& Zingales, 1995). The agency cost theory argues that firms can maintain an optimal capital structure by mitigating the cost arising from the conflict across the shareholders (Jensen, 1986). These agency conflicts arise as a result of the diversion between ownership and control. Moreover, prior literature link capital structure theory in the behavioural context of the agency relationship between principal and agent. The static narrative of agency context predicts that professional managers tend to use their power and control to extract private benefit at the cost of value maximising actions of the firm (Jensen \& Meckling, 1976).

Further, financial hierarchy theory suggests a hierarchy of financing; to employ internal funds in the first preference, followed by leverage financing, and finally, the equity shareholdings. The extant literature has addressed the dynamics of capital structure from various expect while the understanding of how firms choose their capital structure is an important empirical question which is extensively addressed by the extant literature.

The trade-off theory postulate that firms maximise shareholders value when the benefits of leverage (e.g. the disciplinary mechanism of leverage and the tax shield) equal the marginal cost of leverage (such as financial distress and bankruptcy cost). Broadly speaking, trade-off theory speaks that firms can target their optimal capital structure by a trade-off between tax benefits and financial distress costs. Moreover, there is a possibility that the leverage financing may use by the controlling shareholders for minority shareholders' expropriation. Further, the probability of bankruptcy would be greater when there is a higher level of leverage financing, particularly beyond the optimal level. The controlling shareholders are reluctant to raise equity as the market value of shares tend to be undervalued, thus prefer leverage financing (Myers \& Majluf, 1984). Furthermore, in most of the developed economies, leverage financing serves as a mechanism to discipline management (Abor, 2008). In the opposing scenario, controlling shareholders prefer leverage financing as a tool to maintain investors' confidence (Ross, 1977).

\subsection{Excess and lower control ownership}

Ownership concentration is prevalent across emerging and developed market and literature emphasize the role of leverage financing in mitigating the agency conflicts (Arslan-A, Karan, \& M., 2006). La Porta et al. (1999) has examined 27 developed countries and report highly concentrated ownership while Claessens et al. (2000) reveal that $66 \%$ of firms in nine East Asian countries are managed and control by large controlling shareholders. However, the empirical literature related to ownership concentration and leverage shows mixed results. For example, Schmid, Achleitner, and Kaserer (2013) examine a sample of German firms and argues that controlling shareholders prefer leverage financing to maintain their controlling stake. Lundstrum (2009) points out that in the case of high concentration of controlling rights the blockholders prefer a higher level of leverage which is supportive in monitoring firms' strategic affairs. Moreover, Mishra and McConaughy (1999) reveal a negative association between ownership concentration and leverage financing and document that the controlling shareholders intended to minimize controlling risk exposure. In contrast, Santos et al. (2014) examine a sample of 12 Western European firms and report a negative relationship between ownership concentration and firms leverage. Lee and Kuo (2014) document that shareholders with lower voting rights presumably prefer less leverage financing to avert the scrutiny of creditors.

We classify our sample into two categories i.e. excess control (majority controlling shareholders) and lower controlling stake (controlling shareholders with a lower fraction of equity) and determine their impact on leverage financing in the Singaporean context. We examine whether the higher level of controlling shareholder ownership directly associate with higher leverage level. In addition, we ascertain whether shareholders with an excess controlling stake are using leverage for minority shareholders' expropriation and link our econometric model in the context of Type II agency conflict. For example, the shareholders with excess controlling rights may avoid to issuing shares to maintain their controlling stake which leads to monitory shareholders' expropriation.

The rationale of excess control and leverage relationship is evident as the of exacerbation of traditional agency conflicts as a result of ownership concentration may have a substantial implication on the corporate sectors and the economy as a whole. On the other hand, controlling shareholders with a lower fraction of equity (lower control) may also prefer leverage over equity to inflate their controlling stake to protect them from expropriation. Moreover, shareholders with a lower controlling stake have less incentive to monitor managers and prefer higher leverage. We conjecture that the association between controlling shareholders and leverage is presumably changed in accordance with the controlling shareholders' stake in equity ownership due to the 'incentive' and 'entrenchment' effect. We also expect that excess and lower control ownership may exhibit distinct financing behaviour towards leverage financing due to the difference in their privileges and investment priorities. we hypothesize:

Hypothesis 1. The relationship between controlling shareholders ownership (CS_Own) and leverage financing differs across Excess control and lower control ownership. 


\subsection{Separation of ownership and control}

The prior studies, such as La Porta et al. (1999) and Claessens et al. (2000) primarily recognized that most of the non-US and East Asian firms display a higher magnitude of the separation of control rights and cash flow rights. The higher degree of separation of ownership and control is related to the larger interest of the controlling shareholders to divert the firm resources for personal benefits at the cost of the minority shareholders' interest (Claessens, Djankov, Fan, \& Lang, 2002).

Another potential reason for controlling shareholders' preference for leverage over equity is to develop an impression for potential investors that management is maintaining a culture of good CG practice even there is a significant divergence between control rights and cash flow rights. In contrast, higher leverage may restrict the controlling shareholders from tunnelling the firm's resources such as direct the firms' assets, personal loan guarantees, asset sales, and future business contract to themselves for personal gain which may induce controlling shareholders towards lower leverage (Du \& Dai, 2005).

Jensen and Meckling (1976) linked the traditional agency issue with the implications of the separation of ownership and control by considering the agency cost. Likewise, Maury \& Pajuste, 2002 reveal that effective CG tends to address the agency problems particularly the issues caused by the deviation of ownership and control. Prior studies such as (Claessens et al., 2002; Lemmon \& Lins, 2003) report a negative impact of separation of cash flow and control rights on firm value. Cronqvist and Nilsson (2003) investigate a sample of Swedish firms and report that separation of ownership and control rights, particularly in family firms, use multiple voting shares which negatively impact on firms' value.

Faccio and Lang (2002) investigate a large European data set and highlight the proportional sharing benefit in the case of separation of ownership and control. Nenova (2003) document that the legal environment, takeover regulations, the law in order and governance regulations define much of the variations across countries in terms of the impact of the separation of ownership and control. Therefore, it's more likely that in the case of the higher divergence between cash flow and control rights; the controlling shareholders may prefer leverage over equity finance to inflate their controlling stake for minority shareholders' expropriation. Therefore, in accordance with the existing literature, we expect that the higher level of separation of cash flow and control rights directly influence the leverage decisions in Singaporean market. We hypothesize:

Hypothesis 2. A higher magnitude of separation between cash flow rights and control rights is positively associated with leverage financing.

\subsection{An inverted $U$-shaped nonlinear association between controlling share ownership and leverage}

The controlling shareholders prefer a lower leverage level to avoid the scrutiny of lending agencies thus provide effective monitoring and better strategic decisions which lead to firms' higher performance (Nguyen et al., 2015). Jensen (1986) predict that the firm leverage negatively impacts on external equity financing which in turn increase the shareholder stake of managerial ownership. In addition, controlling shareholders can limit the managerial entrenchment by acquiring less leverage finance which reduces the risk of financial distress (Lee \& Kuo, 2014). Alternatively, entrenchment motives induce professional managers to enhance leverage level above the optimal threshold which more likely to boost their voting strength to influence corporate strategies (Harris \& Raviv, 1988; Stulz, 1988).

Moreover, the entrenched managers tend to prefer a higher leverage level as a momentary tool to build up an impression of selling assets or restructuring business units thus initiate a pre-arrange takeover attempts by outsiders (Berger, Ofek, \& Yermack, 1997). K. Li, Lu, Mittoo, and Zhang (2015) reveal that higher controlling rights inflate entrenchment effects which more likely to lead a higher risk of financial distress. In a similar vein, Lundstrum (2009) reveals that blockholders prefer higher leverage to strengthens their ultimate control which in turn helpful in monitoring firms' strategic affairs.

Contrary to equity financing, the high leverage firms face the increased pressure of debt repayment and default risk when leverage exceeds a certain level of threshold. Therefore, in the case of a nonlinear relationship, a positive relationship between controlling shareholders and leverage continues up to a certain level of threshold i.e. optimal level, as the controlling shareholders intend to maintain their controlling stake; however, financial distress risk is a significant concern for the controlling shareholders which induce them to reduce the leverage at a certain threshold level. Therefore, on average, firms' leverage is more likely to be reduced at a higher stake of controlling shareholders. In addition, when the controlling shareholding increases their stake, it tends to converge their interests with outside shareholders and as a result, leverage is less likely to be used as a tool of minority shareholders' expropriation.

Given the prevalence of concentrated ownership and family-controlled ownership in the Singaporean market, we expect that control ownership-leverage relationship lead to the 'expropriation effect'. However, Singapore holds several characteristics of developed economies e.g., the strong legal and institutional settings, the effectiveness of the rule of law and adequate investor' protection which enhance the efficacy of CG in curbing the expropriation of minority shareholders thus support the likelihood of monitoring/incentive effect. Thus, the likelihood of both opposing effects of control ownership such as 'expropriation effect' and 'monitoring/incentive effect' presumably lead to the inverted-U shape association. These evidences motivate us to investigate whether there is an inverted U-shaped non-linear association between controlling shareholders' ownership and firm leverage. We hypothesize:

Hypothesis 3. There is an inverted $U$-shaped nonlinear association between controlling shareholders' ownership (CS_Own) and leverage financing.

\subsection{Moderating effect of family ownership}

Moreover, the empirical literature related to family-controlled ownership and leverage shows mixed results. For example, SetiaAtmaja (2010) investigate a sample of 316 Australian firms and document that family-controlled firms prefer high leverage compared to non-family firms. The study further reveals that family-controlled firms prefer a higher level of leverage financing to influence minority shareholders in board key decisions. Margaritis \& Psillaki (2010) point out that family-controlled firms prefer leverage financing as a disciplinary tool to mitigate the shareholder-manager agency issues suggesting a positive relationship between family ownership and financial leverage. Likewise, Croci, Doukas, and Gonenc (2011) document a positive relationship between family ownership and leverage financing. Setia-Atmaja, Tanewski and Skully (2009) and King and Santor (2008) examine the Australian and Canadian family firms, respectively and report a relatively higher leverage level than non-family firms.

In the opposing view, Hiebl (2012) claim that risk aversion is most dominant attribute of family ownership firms. Bianco, Bontempi, Golinelli, and Parigi (2013) highlight that family firms' shareholders more likely to concentrate their personal incentives thus prefer lower return with known risks instead of higher returns with uncertain risks. The family-controlled firms may prefer to avoid external monitoring, particularly from creditors and do less reliant on leverage financing. Gama and Galvão (2012) report that family shareholders prefer a higher level of equity than leverage financing to avoid the financial distress. Schmid et al. (2013) document that to avoid bankruptcy and financial distress family-controlled firms in countries where the creditor rights are relatively higher, tend to prefer lower leverage financing than non-family firms. Ampenberger et al. (2011) examine a sample of 
German firms and report that family firms relatively less rely on leverage financing compared to non-family firms whilst a similar result for French family firms document by Margaritis and Psillaki (2010).

Given the study is in the context of Singapore where family-controlled ownership is highly concentrated, we conjecture that familycontrolled ownership as a moderating variable may change the strength and direction of the causal relationship between controlling shareholders' ownership and leverage financing. We hypothesize:

Hypothesis 4. The family-controlled ownership negatively moderates the association between controlling shareholders' ownership and leverage financing.

\section{Data and sample}

The Singapore Exchange Ltd. (SGX) being the primary regulator of publicly listed firms in Singapore, provide two different exchange market requires different listening requirements, such as Mainboard and Catalist. The listed firms of Singapore are required to disclose their CG best practice compliance statement in their annual report, while the compliance with the CG Code is not mandatory. Our preliminary sample consists of all Singaporean non-financial listed firms of SGX Mainboard. We exclude Financial industries (SIC codes, 6000-6999), Utilities (SIC codes, 4900-4999), and firms listed on the SGX Catalist, subject to differences in listing and regulatory requirements (Bauer, Frijns, Otten, \& Tourani-Rad, 2008; Du \& Dai, 2005; Nguyen et al., 2015; Schultz, Tan, \& Walsh, 2010; Yusuf, Yousaf, \& Saeed, 2018). In addition, we excluded all those firms whose ownership or shareholders' voting data is incomplete, as it's not possible to track the pyramidal ownership until to have access to ultimate controlling shareholders. We also exclude those firm's data which are either, completely missing or available data showing less than half of the firm's ownership rights. This results in an unbalanced panel dataset of 310 firms covering the period 2008-2016. The Singaporean code of CG, first promulgated by the CG committee in 2001, hereafter reviewed in 2005 and became effective with a substantive amendment from September 2007. We, therefore, selected the sample year 2008 as it is one year after the promulgation of revised CG regulations in Singapore. In addition, the Singaporean code revised in 2012 mainly to ensure a balanced composition of corporate boards in terms of executive and independent INEDs. We test the release of regulations (2012) as a natural exogenous shock to determine its impact on the relationship between control ownership and leverage decisions. The financial data are extracted from Worldscope 'One Banker' (financial module), while ownership and voting data are obtained from firms' individual annual reports and supplemented by Worldscope 'One Banker' (Ownership module).

\subsection{Measurement of variables}

Following prior studies such as Claessens et al. (2000) and Faccio and Lang (2002), we measure controlling share ownership (CS_Own) by collecting control rights and direct ownership related to the largest shareholders and estimate in our model as an independent variable.

In order to conduct an in-depth analysis, we classify our sample into two categories i.e. firms dominated with the excess control (majority controlling shareholders) and lower control (controlling shareholders with a lower fraction of equity) and determine their impact on leverage financing. We classify a firm as an excess control when the sum of voting rights held by the first three largest controlling shareholders is $50 \%$ or above the total equity (family members or others as per the agreement), while the voting stake of the first three largest shareholders is $20 \%$ or less of total equity is considered as a lower control. We estimate the financing behaviour of controlling shareholders across excess and lower control as Type II agency conflict (principal vs principal) as it arises between excess and lower. In addition to our main independent variable i.e. controlling shareholders ownership, we further investigate the magnitude of separation of cash flow rights and control rights using three different wedge scales and determine their impact on firm leverage decisions. These wedge scales examine the magnitude of divergence between ownership and control, while in a theoretical context, a higher degree of wedge scales lead to Type II agency conflict. We defined wedge scale- 1 as the fractional difference between cash flow rights and control rights. The wedge scale- 2 measured as the percentage of cash flow rights to control rights of the largest shareholders, whilst wedge scale- 3 is the dummy variable that equals to 1 if control rights of the largest shareholders are greater than cash flow rights.

We estimate the role of family-controlled firms as a moderating variable to determine whether the association between controlling shareholders' ownership is influenced by family-controlled ownership. We classify a firm as a family-controlled firm, where a family member is the CEO or chairman and hold at least $5 \%$ equity. Based on this criterion, we found that $43.2 \%$ of the sample as family firms. ${ }^{1}$

We estimate leverage as the main dependent variable of our model. The extant literature used two alternative measures of firm leverage by considering the market or the book value (Antoniou, Guney, \& Paudyal, 2008; Henry Agyei-Boapeah, 2015; Sogorb-Mira, 2005). Therefore, for the robustness of our results, we incorporate two alternate measurements of leverage e.g. based on the book value of equity and market value of equity. In addition, we include six core factors affecting firm leverage in our model estimation as control variables such as firm size, market-to-book-ratio (MTB), tangibility, NDTS (non-debt tax shield), profitability and Volatility (Schmid et al., 2013). We begin our analysis by examining the impact of controlling shareholders' ownership on the firms' leverage by considering the full sample:

Debts $(\mathrm{k})_{\mathrm{it}}=\alpha_{0}+\alpha_{1} \mathrm{CS} \_O \mathrm{wn}_{\mathrm{it}}+\gamma_{X}$ Controls $_{\mathrm{k}, \mathrm{it}}+\varepsilon_{i t}$

where debts represent firm leverage measured with two alternate criteria i.e. book and market value, while CS_Own is controlling shareholders ownership. Moreover, $i$ and $t$ represent cross-sections and time period respectively, while $\varepsilon_{i t}$ is the error term. In addition, we test whether there is a non-linear association between CS_Own and firm leverage. Accordingly, we include CS_Own and its square value $\left(\mathrm{CS} \_\mathrm{O} n^{2}\right)$ into model estimation:

$$
\text { Debts }(\mathrm{k})_{\mathrm{it}}=\alpha_{0}+\alpha_{1} \text { CS_Own }{ }_{\mathrm{it}}+\alpha_{2} \mathrm{CS}_{-} \mathrm{O} \mathrm{wn}^{2}{ }_{\mathrm{it}}+\gamma_{X} \text { Controls }_{\mathrm{k}, \mathrm{it}}+\varepsilon_{i t}
$$

where CS_Own representing controlling shareholders ownership. The square value (CS_Own ${ }^{2}$ ) determines whether there is a quadratic relation between controlling shareholders' ownership and financial leverage. Moreover, we expect a positive coefficient sign of CS_Own while a negative coefficient on $\mathrm{CS}_{-} \mathrm{O} w n^{2}$ representing the highest point. Table 1 explains the definitions of the variable used in the study.

\section{Empirical model}

The extant literature reports a significant influence of ownership structure on the firms' leverage, however, most of the prior studies of capital structure have ignored the endogeneity problem. (Amin \& Williamson, 2020; De La Bruslerie \& Latrous, 2012; Lo et al., 2016). GMM estimator produces a more consistent and efficient estimation after controlling the potential source of endogeneity. Moreover, GMM modelling supported by the prior study of Hermalin and Weisbach (1991) who used the lagged levels of ownership variables by considering the changes in ownership structure over time.

We thus estimate our model by employing GMM estimator and compare its results with static models i.e. OLS and fixed effects to understand the biases that arise from ignoring endogeneity.

\footnotetext{
${ }^{1}$ Prior studies employ a number of different definitions to define what constitutes a family firm (Hasso and Duncan, 2013; Weiss 2014). Therefore, the present study defined family ownership based on literature.
} 
Table 1

Explains the definitions of the variable used in the study.

Variables definitions and sources

\begin{tabular}{|c|c|}
\hline Variable & Description \\
\hline Control rights (CS_Own) & Proportion of control rights owned by the 10 largest controlling shareholder \\
\hline CS_Own $n^{2}$ & Square value of control rights owned by the controlling shareholder \\
\hline Cash flow rights & Proportion of cash flow rights owned by the 10 largest controlling shareholder \\
\hline Excess Control (Majority) & Sum of the voting rights held by the first three largest controlling shareholders is $50 \%$ or above \\
\hline Lower Control (Non-majority) & Sum of the voting rights held by the first three largest controlling shareholders is $20 \%$ or less \\
\hline Control rights ( $1^{\text {st }}$ largest) & Proportion of First largest control rights \\
\hline Control rights ( $2^{\text {nd }}$ largest $)$ & Proportion of Second largest control rights \\
\hline Control rights ( $3^{\text {rd }}$ largest) & Proportion of Third largest control rights \\
\hline Cashflow rights ( $1^{\text {st }}$ largest) & Proportion of First largest cash flow rights \\
\hline Cashflow rights ( $2^{\text {nd }}$ largest) & Proportion of Second largest cash flow rights \\
\hline Cashflow rights ( $3^{\text {rd }}$ largest) & Proportion of Third largest cashflow rights \\
\hline Wedge 1 & Fractional difference between cash-flow rights and control rights \\
\hline Wedge 2 & Percentage of cash-flow rights scaled by control rights of the largest controlling shareholders \\
\hline Wedge 3 & Dummy variable that equals to 1 if control rights of largest shareholders are greater than cash-flow rights, 0 otherwise \\
\hline FCO & Proportion of family-control ownership \\
\hline Family managers representation & Proportion of family managers representation in family-control firms \\
\hline Family board representation & Proportion of family board members representation in family-control own \\
\hline Pyramidal Ownership & Dummy variable equal to 1 if firm control through pyramidal ownership structure, 0 otherwise \\
\hline Non-Family Control & Proportion of family-control ownership \\
\hline Corporation & Proportion of Corporations \\
\hline Financial & Proportion of Financial firms \\
\hline State (GLCs) & Proportion of government-link Corporations \\
\hline Leverage (Book value) & Ratio of total debt scaled by total debt plus book value of equity \\
\hline Leverage (Market value) & Ratio of total debt scaled by total debt plus market value of equity \\
\hline Ln (Firm Size) & Natural logarithm of book value of total assets \\
\hline Ln (MTB) & Market value of the equity scaled by book value of equity(natural logarithm) \\
\hline Tangibility & Ratio of Fixed Assets (property, plant and equipment) scaled by Total Assets \\
\hline NDTS & Non-debt tax shield: Annual depreciation expense scaled by net assets \\
\hline Profitability & Ratio of EBITDA to total assets \\
\hline Volatility & Standard deviation of the change in operating EBITDA over the previous four years \\
\hline Regulations 2012 & Dummy variable that equals to 1 if the sample year is 2012,0 otherwise \\
\hline Source of Data & Firm's annual reports; Worldscope (Ownership \& Financial modules), Osiris data base \\
\hline
\end{tabular}

\section{Empirical results}

\subsection{Summary statistics}

Following La Porta et al. (1999) and Claessens et al. (2000), we calculate the ultimate cash flow and control rights in the hands of the 10 largest controlling shareholders. Therefore, panel A of Table 2 shows that on average, the concentration of control rights is $67.4 \%$, while cash flow rights are $64.5 \%$, indicating that control rights are slightly greater than cash flow rights by considering that the firm level largest controlling shareholders has at least $5 \%$ of the total voting stake. These statistics congruent with the findings of (Claessens et al., 2000) who reported that control rights are larger than cash flow rights particularly in the case of Indonesia, Japan, and the Singaporean firms. ${ }^{2}$ It is notable that unlike other emerging economies the degree of separation between cash flow rights and control rights in Singapore is not significantly high. This separation between cash flow rights and control rights is because of the presence of cross holdings, business groups and pyramids ownership in the Singaporean market which allow controlling shareholders to dominate in board decision making.

On average, the first-largest shareholder has $27.3 \%$ of the control rights and $24.5 \%$ of cash flow rights. While the average control rights (cash flow) for the second and third-largest shareholders are 13.5\% (11.4\%) and 6.71\% (5.66\%), respectively. These statics exhibits a

\footnotetext{
${ }^{2}$ These statistics are marginally different from the descriptive statistics reported by Claessens et al. (2000). Basically, Claessens et al. (2000) examine the Singaporean firm using the sample period of 1996-1998, i.e. the period during which the CG in Singapore was in the developing stage. Whilst the present study takes into account the fresh data set i.e. 2008-2016 thus revise the previously established results regarding the separation of ownership and control in the Singaporean context.
}

significant level of controlling shareholders' ownership in the Singaporean market which is congruent with the findings of Claessens et al. (2000), who report that control rights are greater than cash flow rights particularly in Indonesia, Japan, and Singapore.

Notably, first, second and the third wedge ratio are 2.90, 1.04 and 1.15 , respectively, indicating a lower level of divergence between ownership and control in the Singaporean market. The growing literature reveals that the higher magnitudes of separation between ownership and control lead to Type II agency conflict. However, this lower level of wedge across three largest controlling owners is not supporting the likelihood of the risk of minority shareholders' expropriation in the Singaporean context which contradicts the scenario of other emerging markets. Moreover, this marginal wedge ratio is because of the dominance of cross holdings, business groups and pyramidal ownership in Singapore. Importantly, Singaporean governance setting substantively focus on investors' confidence and minority protection which motivate us to investigate whether this marginal diversion between ownership and control may impact on agency relationship and leverage decisions.

Table 2 shows that $63.4 \%$ of the Singaporean firms are dominated by a higher level of shareholders' control (Excess control), while $21.7 \%$ of the firms are representing the lower level of shareholders' control (non-majority control, i.e. controlling shareholders with a lower fraction of equity). Overall, these statistics indicate a dominating position of the majority controlling shareholders over non-majority control in Singapore corporate sector. Panel B of Table 2 illustrates the control rights and cash flow rights across different ownership structures. The family-control ownership is the most frequent ownership type among the largest controlling shareholders (43.3\%). In this regard, our analysis shows that Singaporean family-controlled firms have substantial representation the corporate board and key managerial roles. In addition, we argue that where the family is the largest shareholder, the firms 
Table 2

Panel A of presents the summary statistics of the variable used in the study. Panel B illustrates the control rights and cash flow rights across different ownership structures.

\begin{tabular}{|c|c|c|c|c|c|c|c|}
\hline \multicolumn{7}{|c|}{ Panel A. Summary statistics of ownership and control } & \multirow[b]{2}{*}{ SD } \\
\hline Variables & Mean & Median & Min & Max & P25 & P75 & \\
\hline Control rights (CS-Own) & 67.4 & 63.1 & 23.1 & 93.7 & 28.1 & 83.1 & 18.7 \\
\hline Cash flow rights & 64.5 & 62.2 & 21.3 & 91.6 & 27.4 & 82.4 & 19.5 \\
\hline Control rights $\left(1^{\text {st }}\right)$ & 27.3 & 24.6 & 6.34 & 87.4 & 11.4 & 31.2 & 15.4 \\
\hline Control rights ( $\left.2^{\text {nd }}\right)$ & 13.5 & 12.4 & 3.10 & 57.3 & 6.91 & 18.2 & 9.12 \\
\hline Control rights $\left(3^{\text {rd }}\right)$ & 6.71 & 6.40 & 2.11 & 43.1 & 2.91 & 9.13 & 4.32 \\
\hline Cashflow rights $\left(1^{\text {st }}\right)$ & 24.5 & 20.1 & 6.11 & 87.2 & 10.3 & 29.7 & 14.3 \\
\hline Cashflow rights $\left(2^{\text {nd }}\right)$ & 11.4 & 11.3 & 3.10 & 56.1 & 6.90 & 16.1 & 9.11 \\
\hline Cashflow rights $\left(3^{\text {rd }}\right)$ & 5.66 & 5.22 & 2.10 & 42.2 & 2.61 & 9.81 & 4.92 \\
\hline Wedge 1 & 2.90 & 2.87 & 0.95 & 4.23 & 1.42 & 3.41 & 0.55 \\
\hline Wedge 2 & 1.04 & 1.01 & 0.21 & 2.63 & 0.59 & 1.823 & 0.47 \\
\hline Wedge 3 & 1.15 & 1.09 & 0.31 & 2.19 & 0.47 & 1.445 & 0.43 \\
\hline Excess Control & 63.4 & 61.31 & 22.5 & 83.2 & 27.9 & 75.6 & 24.2 \\
\hline Lower Control & 21.7 & 21.3 & 3.35 & 34.4 & 9.51 & 32.3 & 9.41 \\
\hline \multicolumn{8}{|c|}{ Panel B. Largest shareholders across Ownership and Control } \\
\hline Family Control & 43.3 & 44.5 & 7.32 & 83.4 & 20.8 & 58.5 & 21.3 \\
\hline Family board representation & 29.4 & 28.7 & 0 & 74.5 & 17.3 & 55.3 & 29.2 \\
\hline $\begin{array}{l}\text { Family managers } \\
\text { representation }\end{array}$ & 17.1 & 12.4 & 0 & 27.3 & 8.41 & 26.4 & 9.51 \\
\hline Pyramidal Ownership & 22.7 & 21.3 & 0 & 52.4 & 10.8 & 30.6 & 23.7 \\
\hline GLCs & 24.1 & 22.4 & 0 & 42.1 & 10.6 & 29.8 & 35.3 \\
\hline Non-Family & 17.5 & 12.3 & 0 & 38.2 & 8.41 & 23.6 & 23.4 \\
\hline Financial & 11.4 & 10.5 & 0 & 17.3 & 5.47 & 15.3 & 9.4 \\
\hline Others & 7.80 & 7.21 & 0 & 12.7 & 3.74 & 10.5 & 6.2 \\
\hline \multicolumn{8}{|l|}{ Independent variable } \\
\hline Leverage (Book value) & 33.2 & 29.9 & 0.002 & 71.3 & 14.9 & 44.7 & 15.3 \\
\hline Leverage (Market value) & 28.1 & 25.3 & 0.001 & 59.2 & 10.8 & 32.8 & 13.5 \\
\hline \multicolumn{8}{|l|}{ Control variables } \\
\hline Firm size & 0.19 & 0.18 & 0.16 & 0.37 & 0.11 & 0.23 & 0.07 \\
\hline MTB & 0.03 & 0.03 & 0.01 & 0.06 & 0.02 & 0.04 & 0.01 \\
\hline Tangibility & 0.13 & 0.12 & 0.01 & 0.23 & 0.06 & 0.18 & 0.09 \\
\hline NDTS & 0.04 & 0.03 & 0.01 & 0.09 & 0.02 & 0.06 & 0.01 \\
\hline Profitability & 0.09 & 0.09 & 0.02 & 0.16 & 0.04 & 0.12 & 0.04 \\
\hline Volatility & 0.11 & 0.10 & 0.03 & 0.19 & 0.06 & 0.15 & 0.05 \\
\hline
\end{tabular}

prefer to appoint their family members as a representative at managerial and senior-level positions. For example, our statistics show that the Singaporean family firms' members have $29.4 \%$ representation on the corporate board. Further, our data analysis shows that on average, $17.1 \%$ of the family-controlled firms appointed their members at senior-level positions.

We conjecture that the presence of these family representatives has a significant impact on firm-level CG which help to alleviate Type I agency conflict (principal-agent), whilst may possibly lead to the Type II agency conflict. For example, in the case of family-controlled ownership, the interest of family-managers and controlling shareholders are aligned while at the same time these family managers presumably serve the private benefits of the family-control shareholders at the cost of external/minority shareholders. Going forward, the second-largest ownership type is the GLCs (24.1\%), indicating that like China, GLCs is also common in the Singaporean market. Further, controlling ownership across non-family, financial firms and other firms are $17.5 \%$, $11.4 \%$ and $7.8 \%$ respectively.

Panel A of Table 3 presents the capital stake of controlling shareholders for a threshold ranging from 0 to $100 \%$. We can see that $20.3 \%$ of the sample firms have the highest controlling stake e.g. ranging between $60 \%-70 \%$, indicating a relatively higher percentage of controlling shareholding in the Singaporean corporate sector. Panel B presents the leverage based on the controlling stake of the firms. We can see that leverage increases with the rise in controlling ownership, however, after reaching a certain threshold (e.g., $40 \%$ and $35 \%$ for book and market value, respectively), the leverage level starts decreasing with the increase in controlling ownership indicating an inverted U-shape trend.
Table 3

Panel A of presents the capital stake of controlling shareholders for a threshold ranging from 0 to $100 \%$. Panel B presents the leverage based on the controlling stake of the firms.

\begin{tabular}{lll}
\hline $\begin{array}{l}\text { Panel A: Frequency of Control } \\
\text { rights }\end{array}$ & \\
\hline Control threshold & Proportion & $\mathrm{N}$ \\
\hline $20 \%-30 \%$ & 15.05 & 315 \\
$30 \%-40 \%$ & 8.86 & 209 \\
$40 \%-50 \%$ & 13.7 & 307 \\
$50 \%-60 \%$ & 14.8 & 424 \\
$60 \%-70 \%$ & 20.3 & 572 \\
$70 \%-80 \%$ & 18.8 & 531 \\
Above $80 \%$ & 8.32 & 234 \\
Panel B: Proportion of Leverage across Controlling & \\
Shareholdings & & \\
Leverage threshold & Leverage (Book & Leverage (Market \\
& value) & value) \\
$10 \%-15 \%$ & 33.2 & 27.9 \\
$15 \%-20 \%$ & 33.3 & 27.9 \\
$20 \%-25 \%$ & 34.2 & 28.5 \\
$25 \%-30 \%$ & 34.5 & 28.7 \\
$30 \%-35 \%$ & 34.8 & 28.6 \\
$35 \%-40 \%$ & 34.8 & 28.3 \\
$40 \%-45 \%$ & 31.2 & 28.1 \\
$45 \%-50 \%$ & 31.1 & 27.3 \\
Above 50\% & 30.1 & 27.8 \\
\hline
\end{tabular}

We conduct a univariate analysis of mean and median difference tests across firms' characteristics and present the findings in Table 4. We categories all observations into two main groups based on leverage level: excess leverage firms and low leverage firms. Panel A shows that firms with excess leverage employ a relatively low concentration of controlling stake than those with low leverage (64.3 vs. 70.5 ). Broadly speaking, this result reflects that firms with a lower level of controlling stake tend to prefer more leverage financing than firms with a higher controlling stake. Interestingly, excess leverage group shows a relatively lower proportion of family-controlled firms (41.5) than lower leverage group (45.1), supporting the argument that family firms' in Singapore are not preferred leverage over equity to maintain their controlling stake. In addition, Pyramidal ownership firms have a higher leverage ratio than non-pyramidal firms. However, there is no significant difference in GLCs across excess and lower leverage groups. Moreover, results show that the high leverage firms are larger in size than those of low leverage firms. The univariate analyses further reflect that there is not a significant difference between both the groups regarding control variables such as MTB, tangibility, NDTS, profitability and volatility.

Panel B of Table 4 presents a preliminary investigation to understand how controlling shareholders ownership influence leverage financing. Using the mean values, L_1 represents the book value of leverage while $L_{-} 2$ denotes the market value of leverage across all groups i.e. full sample, family ownership, GLCs and pyramidal ownership. The observations are classified into deciles, incorporating the bottom (lower) and the top (highest) group of control ownership. Before considering other factors, the analysis shows that firms' leverage constantly decreases with the increase in the concentration of controlling ownership reflecting that as the level of controlling stake increases, firms reduce their leverage financing. However, the analysis shows that family-controlled and pyramidal ownership firms are relatively more rely on leverage financing than GLCs group firms.

\subsection{Impact of controlling shareholders' ownership (CS_Own) on firms' leverage}

We begin with our baseline analysis by examining the relationship between controlling shareholders' ownership (CS_Own) and leverage 
Table 4

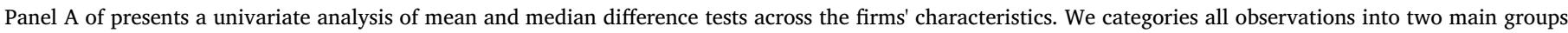

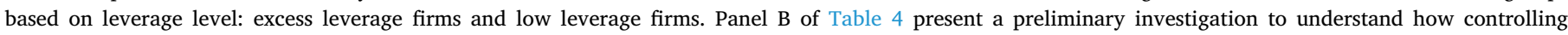

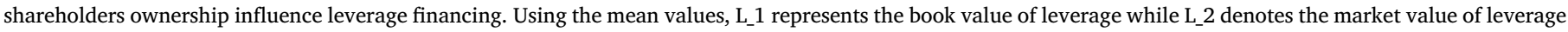
across all groups i.e. full sample, family ownership, GLCs and pyramidal ownership.

\begin{tabular}{|c|c|c|c|c|c|c|c|c|c|}
\hline \multicolumn{6}{|l|}{ Univariate Analysis: } & & & & \\
\hline \multicolumn{10}{|c|}{ Panel A: Firms characteristics across Excess and Low Leverage level } \\
\hline Variables & \multicolumn{2}{|l|}{ Excess } & \multicolumn{2}{|l|}{ Low } & \multicolumn{2}{|l|}{ Difference } & \multicolumn{2}{|l|}{ t-Stat } & $Z$-stat \\
\hline Leverage (Market) & 37.5 & & 28.9 & & 8.60 & & $5.23^{* *}$ & & $2.76^{* * *}$ \\
\hline Leverage (Book) & 32.9 & & 23.3 & & 9.60 & & $2.44 * * *$ & & $1.97^{*}$ \\
\hline CS_Own & 64.3 & & 70.5 & & -6.20 & & $4.11^{*}$ & & $9.23^{* * *}$ \\
\hline Family Control & 41.5 & & 45.1 & & 3.60 & & $1.22 *$ & & $6.38^{* *}$ \\
\hline Pyramidal Ownership & 23.9 & & 21.5 & & 2.40 & & $4.19 * * *$ & & $3.99^{* * *}$ \\
\hline GLCs & 23.9 & & 24.3 & & -0.40 & & $7.22 * *$ & & $4.28^{*}$ \\
\hline Firm size & 0.20 & & 0.18 & & 0.02 & & $6.17^{*}$ & & $4.12^{*}$ \\
\hline МТВ & 0.04 & & 0.02 & & 0.02 & & 1.86 & & $8.89^{* * *}$ \\
\hline Tangibility & 0.11 & & 0.15 & & -0.04 & & 2.14 & & 6.05 \\
\hline NDTS & 0.04 & & 0.04 & & 0.00 & & $5.11^{* * *}$ & & $3.97^{* *}$ \\
\hline Profitability & 0.07 & & 0.11 & & -0.04 & & $7.66^{*}$ & & 2.36 \\
\hline Volatility & 0.11 & & 0.11 & & 0.00 & & $4.39 * * *$ & & $1.99^{* * *}$ \\
\hline \multicolumn{10}{|c|}{ Panel B: Mean Leverage threshold across Controlling Shareholders } \\
\hline Controlling Stake & Full Sa & & Fami & & GLCs & & Pyramidal & & \\
\hline Decile & L_1 & L_2 & L_1 & L_2 & L_1 & L_2 & L_1 & L_2 & \\
\hline 1 (Bottom) & 38.4 & 34.6 & 39.5 & 35.7 & 38.2 & 34.4 & 39.4 & 35.6 & \\
\hline 2 & 38.3 & 34.5 & 39.4 & 35.4 & 38.1 & 34.3 & 39.3 & 35.3 & \\
\hline 3 & 36.2 & 32.4 & 36.3 & 33.3 & 36.4 & 32.6 & 36.2 & 33.4 & \\
\hline 4 & 36.1 & 32.3 & 36.3 & 32.2 & 36.3 & 32.5 & 36.2 & 32.3 & \\
\hline 5 & 34.5 & 30.7 & 35.2 & 31.4 & 34.4 & 30.6 & 35.3 & 31.4 & \\
\hline 6 & 34.3 & 30.5 & 35.1 & 31.4 & 34.4 & 30.6 & 35.2 & 31.4 & \\
\hline 7 & 30.1 & 26.3 & 29.4 & 25.1 & 30.2 & 26.4 & 29.5 & 25.2 & \\
\hline 8 & 30.1 & 26.3 & 29.4 & 25.1 & 30.2 & 26.4 & 29.5 & 25.2 & \\
\hline 9 & 29.5 & 25.7 & 28.2 & 24.7 & 29.4 & 25.6 & 28.2 & 24.6 & \\
\hline 10 (Тор) & 29.5 & 25.7 & 28.2 & 24.7 & 29.4 & 25.6 & 28.2 & 24.6 & \\
\hline
\end{tabular}

P-values are reported in parentheses, whereas, ***; **; * represent significance at the 1\%, 5\%, and $10 \%$ level,respectively.

for the full sample and present the results in Table 5. Model 1-2 presents the regression with two alternate proxies of leverage: book and market value. The coefficients on CS_Own are negatively significant in both the models indicating that controlling shareholders prefer equity over leverage financing to maintain the optimal capital structure. This result suggests that controlling shareholders less rely on leverage financing to minimize the likelihood of financial distress and default risk.

\section{Table 5}

Presents our baseline estimation. Model 1-2 shows the regression using two different proxies of leverage e.g. Book value of leverage define as the ratio of total debt scaled by total debt plus book value of equity and Market value of leverage define as the ratio of total debt scaled by total debt plus the market value of equity. FCO is family control ownership. Firm size is defined as the natural logarithm of the book value of total assets; MTB: market value of the equity scaled by book value of equity; Tangibility:ratio of fixed assets to total assets; NDTS (Non-debt tax shield): ratio of annual depreciation to total assets; Profitability: ratio of EBITDA to total assets; Volatility: standard deviation of the change in operating EBITDA over the previous four years. Year and industry dummies are included in all models. ${ }^{* *} p<0.001 ;{ }^{* *} \mathrm{p}<0.01 ;{ }^{*} \mathrm{p}<0.05$; (all two-tailed tests).

Impact of control ownership (CS_Own) on firm's leverage (Baseline estimation)

\begin{tabular}{lll}
\hline Variables & $(1)$ & $(2)$ \\
\hline CS_Own & $-0.019^{* * *}(0.001)$ & $-0.377^{* *}(0.021)$ \\
Regulations-2012 & $0.311(0.118)$ & $0.402(0.213)$ \\
Firm size & $-0.616^{* *}(0.021)$ & $-0.031^{* *}(0.036)$ \\
MTB & $0.322^{*}(0.086)$ & $0.147^{* *}(0.019)$ \\
Tangibility & $0.399^{*}(0.092)$ & $0.025^{* *}(0.042)$ \\
NDTS & $-0.162(0.331)$ & $-0.271^{* *}(0.022)$ \\
Profitability & $-0.514^{*}(0.089)$ & $-0.106^{* *}(0.031)$ \\
Volatility & $0.532(0.661)$ & $0.427(0.352)$ \\
R-sq & 0.43 & 0.57 \\
Observations & 2592 & 2592
\end{tabular}

In this scenario, when the controlling ownership exceeds a certain threshold, leverage becomes less important for controlling shareholders in terms of better CG practice. Importantly, this result contradicts the prior literature that controlling shareholders pursue non-dilutive entrenchment motives at the cost of minority shareholders' interest (see, for example, Boubaker, 2008; Bianco \& Nicodano, 2006; Claessens et al., 2000; Claessens et al., 2002; Faccio \& Lang, 2002; King \& Santor, 2008). In addition, the Singaporean code revised in 2012 mainly to ensure a balanced composition of corporate boards in terms of executive and independent INEDs. We, therefore, incorporate the dummy variable for regulations (2012) to determine whether the release of regulations impact on the relationship between control ownership and leverage decisions. The results show that coefficient on regulations (2012) is insignificant indicating that regulations have no impact on control ownership and leverage relationship.

In terms of control variables, MTB and tangibility are positively significant while firm size, profitability and NDTS are negatively significant. The positive coefficient on MTB exhibits that firms with higher market value tend to prefer higher leverage ratio whereas, the positive coefficient on tangibility implies that firms use the higher assets tangibility as collateral of debt. The negative coefficient on firm size implies that controlling shareholders reduce their cash flow rights with an increase in firm size. The profitability is negatively significant, supporting the prediction of financial hierarchy theory that highly profitable firms tend to more rely on internal financial resources. The NDTS is negatively significant indicating that Singaporean firms are expected to receive a higher tax benefit from the debt financing thus prefer a higher level of leverage. Moreover, the coefficient on volatility is insignificant suggesting that uncertainties in the Singaporean corporate sector are relatively low as the Singaporean market is characterized by the strong institutional setting and better corporate culture. 
6.3. Impact of controlling shareholders' ownership on firm leverage across excess and lower level of control

To gain further insight into the impact of controlling shareholders' ownership on leverage and to examine the significance of Type II agency conflict, we investigate whether the relationship between controlling shareholders' ownership and leverage differs across excess and lower level of shareholders' control. Accordingly, we classify our sample into two categories i.e. excess controlling and lower controlling stakes. To test the robustness of results, all models are estimated based on two different scales of leverage i.e. book value and market value, respectively. In the previous analysis, we use static models to examine controlling shareholders' ownership and leverage relationship without considering the potential source of endogeneity. In the next line analysis, we gauge the relationship between controlling share ownership and firm leverage in the dynamic framework by employing a two-step system GMM estimator with bias-corrected robust standard errors.

Table 6 shows that the coefficients on CS_Own for excess control are significantly negative across the models $1-6$, except static model 2 which is consistent with our baseline results reported in Table 5 . These findings reflect that controlling shareholders with excess/higher controlling stake focus on value maximisation rather using leverage as a tool of minority shareholders' expropriation. Importantly, this result is in contrast to the prior literature which documents that controlling shareholders prefer higher leverage financing to dilutes the power and authority of minority shareholders (Bianco \& Nicodano, 2006; Boubaker, 2008; Faccio \& Lang, 2002; King \& Santor, 2008). In addition, this result shows that the controlling shareholders with excess control do less rely on leverage financing to minimize the likelihood of default risk. These findings also exhibit that when controlling ownership exceeds a certain threshold, leverage financing becomes less important for controlling shareholders in terms of better CG practice. This situation motivates controlling shareholders to prefer equity over leverage financing to reduce the likelihood of financial distress. We report three potential explanations for this result. First, Witt (2012) reports that minority shareholder rights are well secured in the Singaporean market. In addition, the strong disclosure-based environment of Singapore accentuates the extensive disclosure reporting and efficient monitoring mechanisms which effectively protect minority' interests, therefore leverage is less likely to be used for minority shareholders' expropriation.

Second, like many developed economies, such as Australia, Denmark, UK and US, the Singaporean economy has a strong marketbased financial system (World Bank, 2013), hence leverage financing is primarily used for an optimal capital structure in Singapore rather a tool of minority shareholders' expropriation. Third, from controlling shareholders perspective; leverage financing is a costly way of influencing corporate policies, whilst the excess leverage financing accelerates the risk of financial distress and bankruptcy. Theoretically, this result is consistent with the static version of trade-off theory which

Table 6

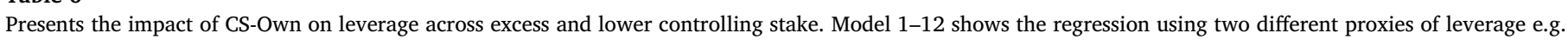

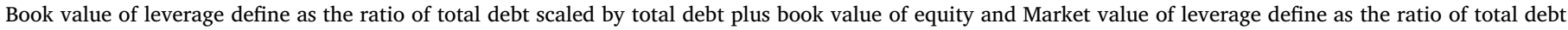

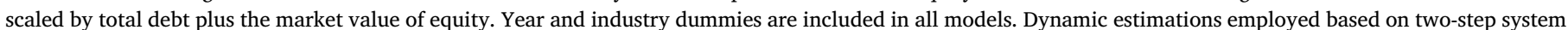

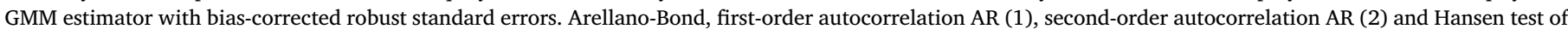

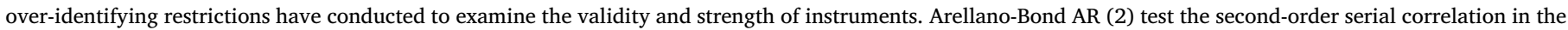

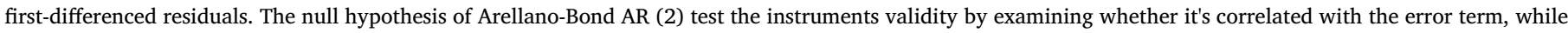

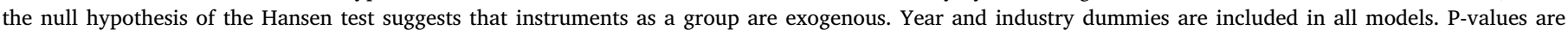
reported in parentheses, whereas, $* * * ; * ; *$ represent significance at the $1 \%, 5 \%$, and $10 \%$ level, respectively.

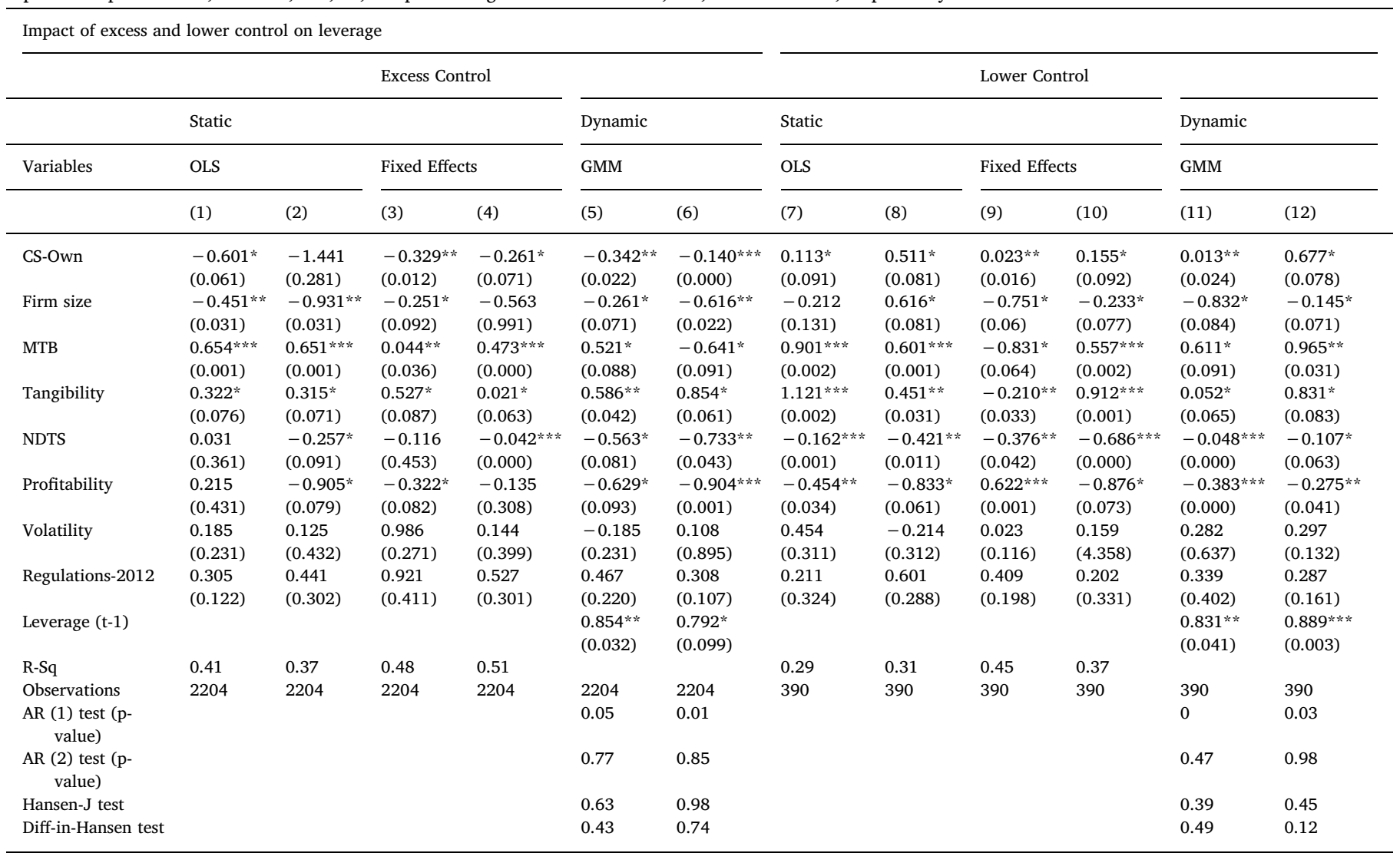


emphasize to equate between the cost of financial distress and tax shielding for an optimal capital arrangement. Importantly, these findings are incongruent with the previous empirical evidence which established that control ownership with excess control rights could threaten the interests of minority shareholders (see, for example, Abdullah \& Pok, 2015; Boubaker, 2008; and Brailsford et al., 2002). We argue that the Singaporean market has a comparative advantage over the fellow emerging market in terms of strong institutional framework and better CG mechanisms which in turn, better converge with the interests of economic actors.

On the other hand, in the case of lower control, the coefficients on CS_Own are positive across the models 7-12, indicating that controlling shareholders with a lower fraction of equity prefer leverage over equity to inflate their equity stake. We report two potential explanations of this result. First, despite the fact that the Singaporean market is widely recognized as a country with effective CG mechanisms, the compliance of Singaporean CG is voluntary which may allow more leeway for nonmajority controlling shareholders to prefer leverage financing to protect them from potential takeovers and mergers. Second, at some point, it's more likely that the majority controlling shareholder would not have any objection on minority controlling shareholders' preference for leverage over equity financing as leverage accompanied the benefit of tax shields. Importantly, we argue that this result displays the unique setting of the Singaporean market which alters the prior empirical research reflecting the distinct role of non-majority controlling shareholders who prefer leverage to inflate their controlling stake. Based on these findings we accept hypothesis 1 . We observe that the explanatory power of regressors are relatively higher in the case of dynamic estimation than static models. The results also show that coefficients on regulations (2012) are insignificant across all the models indicating that regulations have no impact on control ownership and leverage relationship. Furthermore, the coefficients on control variables are almost similar to those reported in Table 5.

\subsection{Effects of separation of ownership and control}

In the next step, we investigate the impact of the separation of ownership and control on the firm leverage and present the results in Table 7. The degree of separation of cash flow rights and control rights is measured using three alternate proxies wedge scale. The prior literature document that wedge reflects the likelihood and extent of expropriation by the majority controlling shareholders (see, for example, Boubakri and Ghouma, 2010; Claessens et al., 2000; Faccio \& Lang, 2002).

Models 1-6 show the impact of the separation of ownership and control rights on firm leverage decisions across two alternate measures of leverage e.g., book and market value. The result clearly shows that the coefficients on wedge scale1-3 appear to be insignificant across all the models except model 6, indicating that the separation of cash flow rights and the control rights are not affecting firm leverage decision. In general, a higher magnitude of separation of ownership and control gives more discretion to the controlling shareholders to influence the firm key decision which is not the case in the Singaporean market.

This insignificant relationship between the separation of ownership and control and leverage financing reflecting that controlling shareholders are not extracting private benefit of control at the cost of the minority shareholder by employing leverage financing. Therefore, this result supports the likelihood of the alignment of interest between the majority controlling shareholders and external/minority shareholders. The potential explanation of this result is that the strong institutional arrangements and judicial environment of Singaporean market adequately protect the minority' interest thus the separation between ownership and control is not becoming the cause of minority shareholders' expropriation. Notably, these findings are in contrast to the classical notion of agency theory that separation of ownership and control lead to minority shareholders' expropriation. Hypothesis 2 predicted that a higher magnitude of separation between cash flow rights and control rights positively associate with leverage. Our findings failed to support hypothesis 2 since the coefficients on wedge1-3 are insignificant across the models $1-5$. Moreover, the control variables are significant with expected signs.

\subsection{U-shaped non-linear relationship between ownership control and leverage}

We next examine whether there is U-shaped non-linear relationship between ownership control and leverage and present the results in Table 8. The results show that coefficients on CS_Own are positively significant across the models $1-2$, i.e. $(\beta=0.865, p<0.01$, model 1$)$, $(\beta=0.477, p<0.10$, model 2$)$, indicating that leverage increases along with the shareholders' controlling stake. Moreover, this relationship varies between high and low level of CS_Own and becomes more robust when the control rights of shareholders are more than their cash flow rights. The coefficients on $\mathrm{CS}_{-} \mathrm{O} \mathrm{wn}^{2}$ are negatively significant for model $1(\beta=-0.144, p<0.01$, model 1$)$, and model 2 $(\beta=-0.123, p<0.10$, model 2$)$, corroborating an inverted U-shaped association (non-monotonic) between controlling shareholders ownership and leverage. This result shows that controlling shareholders prefer to increase the leverage financing to maintain an optimal capital structure reflecting as 'monitoring effect' and at a certain threshold, tend to reduce the leverage level, indicating as 'risk reduction/incentive effect'. More specifically, at first, the firms' leverage increase with CS_Own and then at a certain threshold level, leverage starts decreasing with the proportion of capital stake of the controlling shareholders (Agca \& Mansi, 2008; Brailsford et al., 2002). Based on these findings, we accept the hypothesis 3.

\subsection{Moderating effect of family ownership on CS_Own and leverage relationship}

Finally, we test the moderating effect of family ownership on the relationship between controlling shareholders' ownership and leverage. Accordingly, we incorporate family ownership as a dummy variable and interaction terms of CS_Own and family-controlled ownership $($ CS_Own $\times$ FCO) to estimate the model:

Debts $(\mathrm{k})_{\mathrm{it}}=+\alpha_{1} \mathrm{CS} \_O w n_{\text {it }}+\left(\alpha_{2} \mathrm{CS}_{-} \mathrm{Own}_{\mathrm{it}} \times \mathrm{FCO}_{\mathrm{it}}\right)+\alpha_{5} \mathrm{FCO}_{\mathrm{it}}+\gamma_{X} \mathrm{Controls}_{\mathrm{k}, \mathrm{it}}+\varepsilon_{i t}$

In addition, we develop a dynamic model to address the potential source of endogeneity:

Debts $(\mathrm{k})_{\mathrm{it}}=$ Debts $(\mathrm{k})_{\mathrm{it}-1}+\alpha_{1} \mathrm{CS} \_O w n_{\mathrm{it}}+\left(\alpha_{2} \mathrm{CS} \_O w n_{\mathrm{it}} \times \mathrm{FCO}_{\mathrm{it}}\right)+\alpha_{5} \mathrm{FCO}_{\mathrm{it}}$

$$
+\gamma_{X} \text { Controls }_{\mathrm{k}, \mathrm{it}}+\varepsilon_{i t}
$$

Table 9 present the results of the moderating effect of family ownership on the relationship between CS_Own and leverage across the static and dynamic models using two proxies of leverage i.e. book and market value across all the estimation techniques. Column 1-4 of Table 9 presents the results of static models e.g. OLS and fixed effects estimation, while columns 5-8 exhibits the findings of dynamic models e.g. fixed effects and GMM estimator. Moreover, GMM is our main estimation model while dynamic fixed effects model is used to test the robustness of our results.

Column 7 shows a significant positive coefficient on CS_Own (e.g., $\beta=0.543, p<0.05$, model 7), while a significant negative coefficient on CS_Own ${ }^{2}$ (e.g., $\beta=-0.307, p<0.01$, model 7) indicating an inverted U-shaped association between CS_Own and leverage decisions. Likewise, column 8 also shows a significant positive coefficient on CS_Own (e.g., $\beta=0.213, p<0.01$, model 8), while a significant negative coefficient on CS_Own ${ }^{2}$ (e.g., $\beta=-0.643, p<0.05$, model 8). These findings are consistent with the results report in Table 8. Moreover, these findings suggest that controlling shareholders first rely on leverage to accelerate controlling stake and then reduce the leverage level once their control level reaches the optimal threshold to avoid the 
Table 7

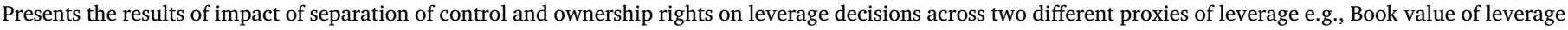

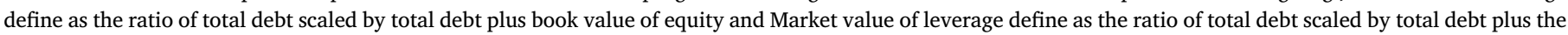

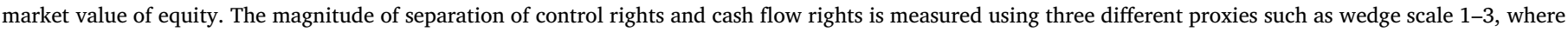

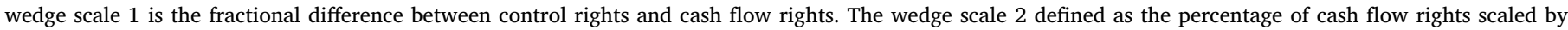

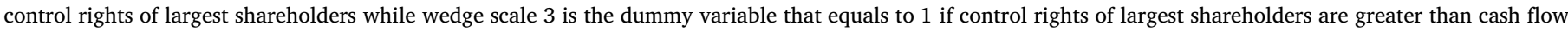

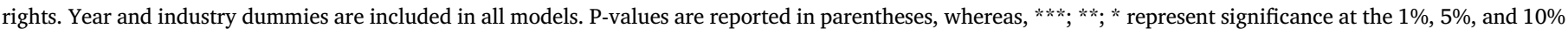
level, respectively.

\begin{tabular}{|c|c|c|c|c|c|c|}
\hline \multicolumn{6}{|c|}{ Impact of separation of Control and Ownership rights on Leverage } & \\
\hline \multirow[t]{2}{*}{ Variables } & \multicolumn{3}{|c|}{ Leverage (Book value) } & \multicolumn{3}{|c|}{ Leverage (Market value) } \\
\hline & (1) & (2) & (3) & (4) & (5) & (6) \\
\hline Wedge 1 & $\begin{array}{l}0.132 \\
(0.641)\end{array}$ & & & $\begin{array}{l}0.134 \\
(0.750)\end{array}$ & & \\
\hline Wedge 2 & & $\begin{array}{l}0.281 \\
(0.165)\end{array}$ & & & $\begin{array}{l}0.049 \\
(0.422)\end{array}$ & \\
\hline Wedge 3 & & & $\begin{array}{l}0.019 \\
(0.249)\end{array}$ & & & $\begin{array}{l}0.792^{*} \\
(0.099)\end{array}$ \\
\hline Firm size & $\begin{array}{l}-0.137^{* * *} \\
(0.000)\end{array}$ & $\begin{array}{l}-0.014^{*} \\
(0.091)\end{array}$ & $\begin{array}{l}-0.143^{* *} \\
(0.041)\end{array}$ & $\begin{array}{l}-0.486^{*} \\
(0.089)\end{array}$ & $\begin{array}{l}0.324 \\
(0.432)\end{array}$ & $\begin{array}{l}-0.973^{*} \\
(0.041)\end{array}$ \\
\hline MTB & $\begin{array}{l}0.149 * * \\
(0.017)\end{array}$ & $\begin{array}{l}-0.343 \\
(0.262)\end{array}$ & $\begin{array}{l}0.055^{* * *} \\
(0.001)\end{array}$ & $\begin{array}{l}0.376^{* *} \\
(0.011)\end{array}$ & $\begin{array}{l}0.134^{*} \\
(0.079)\end{array}$ & $\begin{array}{l}0.116 \\
(0.119)\end{array}$ \\
\hline Tangibility & $\begin{array}{l}0.774 * * \\
(0.027)\end{array}$ & $\begin{array}{l}0.056^{* *} \\
(0.019)\end{array}$ & $\begin{array}{l}0.311^{* * *} \\
(0.000)\end{array}$ & $\begin{array}{l}0.248 \\
(0.432)\end{array}$ & $\begin{array}{l}0.482 * \\
(0.061)\end{array}$ & $\begin{array}{l}0.018^{*} \\
(0.086)\end{array}$ \\
\hline NDTS & $\begin{array}{l}-1.581^{* * *} \\
(0.000)\end{array}$ & $\begin{array}{l}-0.312^{* *} \\
(0.016)\end{array}$ & $\begin{array}{l}-0.292^{*} \\
(0.099)\end{array}$ & $\begin{array}{l}-0.371 \\
(0.324)\end{array}$ & $\begin{array}{l}-0.421^{* *} \\
(0.019)\end{array}$ & $\begin{array}{l}-0.329 * \\
(0.076)\end{array}$ \\
\hline Profitability & $\begin{array}{l}-0.034 \\
(0.275)\end{array}$ & $\begin{array}{l}-0.207^{*} \\
(0.089)\end{array}$ & $\begin{array}{l}-0.091^{* * *} \\
(0.002)\end{array}$ & $\begin{array}{l}-0.267^{*} \\
(0.086)\end{array}$ & $\begin{array}{l}-0.115^{\text {*** }} \\
(0.000)\end{array}$ & $\begin{array}{l}-0.342 \\
(0.553)\end{array}$ \\
\hline Volatility & $\begin{array}{l}0.341 \\
(0.312)\end{array}$ & $\begin{array}{l}0.123 \\
(0.066)\end{array}$ & $\begin{array}{l}0.903 \\
(0.641)\end{array}$ & $\begin{array}{l}0.187^{*} \\
(0.059)\end{array}$ & $\begin{array}{l}0.116 \\
(0.414)\end{array}$ & $\begin{array}{l}0.721 \\
(0.197)\end{array}$ \\
\hline Regulations 2012 & $\begin{array}{l}0.322 \\
(0.118)\end{array}$ & $\begin{array}{l}0.405 \\
(0.211)\end{array}$ & $\begin{array}{l}0.203 \\
(0.192)\end{array}$ & $\begin{array}{l}0.422 \\
(0.186)\end{array}$ & $\begin{array}{l}0.331 \\
(0.202)\end{array}$ & $\begin{array}{l}0.261 \\
(0.172)\end{array}$ \\
\hline Leverage (t-1) & $\begin{array}{l}0.783^{* * *} \\
(0.000)\end{array}$ & $\begin{array}{l}0.799 * * \\
(0.032)\end{array}$ & $\begin{array}{l}0.812^{*} \\
(0.056)\end{array}$ & $\begin{array}{l}0.841^{* * *} \\
(0.000)\end{array}$ & $\begin{array}{l}0.896^{* * * *} \\
(0.000)\end{array}$ & $\begin{array}{l}0.854 * * \\
(0.043)\end{array}$ \\
\hline Observations & 2592 & 2592 & 2592 & 2592 & 2592 & 2592 \\
\hline AR (1) test (p-value) & 0.02 & 0.07 & 0.03 & 0.09 & 0.01 & 0.02 \\
\hline AR (2) test ( $p$-value) & 0.32 & 0.82 & 0.33 & 0.45 & 0.93 & 0.42 \\
\hline Hansen-J test (over identification) & 0.53 & 0.44 & 0.27 & 0.72 & 0.84 & 0.14 \\
\hline Diff-in-Hansen test ( $p$-value) & 0.48 & 0.37 & 0.63 & 0.34 & 0.59 & 0.16 \\
\hline
\end{tabular}

Table 8

Presents the association between CS_Own and its square e.g., CS_Own ${ }^{2}$ across two models e.g., Book value of leverage and Market value of leverage. Firm size is defined as the natural logarithm of the book value of total assets; MTB: market value of the equity scaled by book value of equity; Tangibility:ratio of fixed assets to total assets; NDTS (Non-debt tax shield): ratio of annual depreciation to total assets; Profitability: ratio of EBITDA to total assets; Volatility: standard deviation of the change in operating EBITDA over the previous four years. Year and industry dummies are included in all models. P-values are reported in parentheses, whereas, $* * * ; * ; *$ represent significance at the $1 \%, 5 \%$, and $10 \%$ level, respectively.

\begin{tabular}{lll}
\hline Non-linear U-shaped association between CS_Own and leverage \\
\hline Variables & $(1)$ & $(2)$ \\
\hline CS_Own & $0.865^{* *}(0.000)$ & $0.477^{*}(0.063)$ \\
CS_Own & $-0.144^{* * *}(0.001)$ & $-0.123^{* *}(0.041)$ \\
Firm size & $-0.212^{*}(0.062)$ & $-0.532^{* * *}(0.002)$ \\
MTB & $0.042(0.343)$ & $0.251^{* *}(0.046)$ \\
Tangibility & $0.532^{* * *}(0.000)$ & $0.124^{*}(0.078)$ \\
NDTS & $-0.251^{*}(0.066)$ & $-0.317^{*}(0.064)$ \\
Profitability & $-0.914^{* * *}(0.000)$ & $-0.441^{*}(0.057)$ \\
Volatility & $0.214(0.439)$ & $0.012(0.914)$ \\
Regulations 2012 & $0.203(0.129)$ & $0.421(0.217)$ \\
Observations & 2592 & 2592 \\
Leverage (t-1) & $0.914^{* * *}$ & $0.889^{* *}$ \\
AR (1) test (p-value) & $(0.003)$ & $(0.042)$ \\
AR (2) test (p-value) & 0.09 & 0.04 \\
Hansen-J test (over identification) & 0.45 & 0.93 \\
Diff-in-Hansen test (p-value) & 0.44 & 0.76 \\
\hline
\end{tabular}

higher cost of debt and default risk. We incorporate family-controlled ownership (FCO) as an interaction terms and our results show that the coefficient on (CS_Own $\times$ FCO) is significantly negative (e.g., $\beta=-0.055, p<0.01$, model 7) and (e.g., $\beta=-0.032, p<0.01$, model 7) indicating that family firms prefer equity over leverage to avoid risk of financial distress and default. This result is consistent with our univariate analysis of Table 4 as well. Broadly speaking, the relationship between family-controlled ownership and leverage is more pronounced for family firms due to the poorly diversified investment portfolio in the Singaporean market. This result is in contrast to the prior research due to the unique characteristics of Singapore (see, for example, Anderson \& Reeb, 2003; Croci et al., 2011; King \& Santor, 2008; Setia-Atmaja (2010), while consistent with the findings of Ampenberger et al. (2011). Based on these findings, we accept hypothesis 4.

\subsection{Robustness tests}

We perform a number of robustness tests to check the sensitivity of our results. First, we re-estimate the Eq. (4) with the median value of leverage based on book and market value. Second, we replace the proxy of family-controlled ownership by excluding the condition that the family members hold the CEO or chairman position and own at least $5 \%$ equity stake. Based on this criterion, the mean of sample family-controlled firms increases from $43.2 \%$ to $51.3 \%$. Turning to our control variable, we replace the proxy 'tangibility' by taking the ratio of fixed assets (such as property, plant and equipment) scaled by net assets instead of total Assets. We re-estimate the model by considering these adjustments and present the findings in Table 10. We can see that 
Table 9

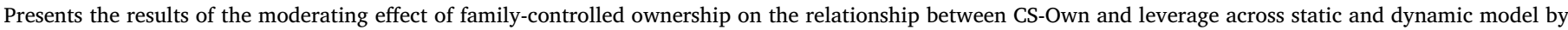

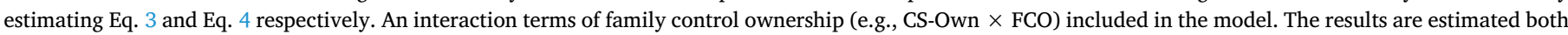

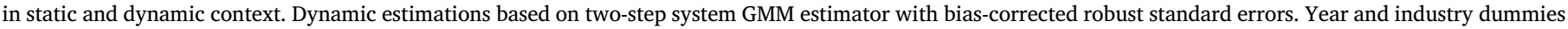
are included in all models. $P$-values are reported in parentheses, whereas, $* * * ; * ; *$ represent significance at the $1 \%$, $5 \%$, and $10 \%$ level, respectively.

\begin{tabular}{|c|c|c|c|c|c|c|c|c|}
\hline \multicolumn{9}{|c|}{ Moderating effect of family-controlled ownership } \\
\hline & \multicolumn{4}{|l|}{ Static } & \multicolumn{4}{|l|}{ Dynamic } \\
\hline & \multicolumn{2}{|l|}{ OLS } & \multicolumn{2}{|c|}{ Fixed Effects } & \multicolumn{2}{|l|}{ Fixed Effects } & \multicolumn{2}{|l|}{ GMM } \\
\hline & (1) & $(2)$ & (3) & (4) & (5) & (6) & (7) & (8) \\
\hline CS-Own & $\begin{array}{l}0.014 * \\
(0.061)\end{array}$ & $\begin{array}{l}0.621 * \\
(0.099)\end{array}$ & $\begin{array}{l}0.033^{*} \\
(0.089)\end{array}$ & $\begin{array}{l}0.452^{* *} \\
(0.039)\end{array}$ & $\begin{array}{l}0.284^{*} \\
(0.083)\end{array}$ & $\begin{array}{l}0.129 * * * \\
(0.000)\end{array}$ & $\begin{array}{l}0.543^{* *} \\
(0.029)\end{array}$ & $\begin{array}{l}0.213^{* * *} \\
(0.002)\end{array}$ \\
\hline CS_Own ${ }^{2}$ & $\begin{array}{l}-0.741^{*} \\
(0.067)\end{array}$ & $\begin{array}{l}-0.314^{* *} \\
(0.032)\end{array}$ & $\begin{array}{l}-0.342^{* *} \\
(0.041)\end{array}$ & $\begin{array}{l}-0.239^{*} \\
(0.078)\end{array}$ & $\begin{array}{l}-0.621^{* *} \\
(0.031)\end{array}$ & $\begin{array}{l}-0.137^{* *} \\
(0.011)\end{array}$ & $\begin{array}{l}-0.307^{* * *} \\
(0.000)\end{array}$ & $\begin{array}{l}-0.643^{* *} \\
(0.022)\end{array}$ \\
\hline FCO & $\begin{array}{l}-0.581 * \\
(0.074)\end{array}$ & $\begin{array}{l}-0.542^{*} \\
(0.098)\end{array}$ & $\begin{array}{l}-0.366^{* *} \\
(0.049)\end{array}$ & $\begin{array}{l}-0.247^{* *} \\
(0.042)\end{array}$ & $\begin{array}{l}-0.243^{* * *} \\
(0.000)\end{array}$ & $\begin{array}{l}-0.219 * \\
(0.910)\end{array}$ & $\begin{array}{l}-0.443^{* * *} \\
(0.000)\end{array}$ & $\begin{array}{l}-0.786^{* * * *} \\
(0.000)\end{array}$ \\
\hline$(\mathrm{CS}-\mathrm{Own} \times \mathrm{FCO})$ & $\begin{array}{l}-0.925 \\
(0.124)\end{array}$ & $\begin{array}{l}-0.258 \\
(0.371)\end{array}$ & $\begin{array}{l}-0.532^{*} \\
(0.077)\end{array}$ & $\begin{array}{l}-0.254^{*} \\
(0.099)\end{array}$ & $\begin{array}{l}-0.042^{* * *} \\
(0.000)\end{array}$ & $\begin{array}{l}-0.098^{* * *} \\
(0.002)\end{array}$ & $\begin{array}{l}-0.055^{\text {*** }} \\
(0.003)\end{array}$ & $\begin{array}{l}-0.032^{* * *} \\
(0.001)\end{array}$ \\
\hline Firm size & $\begin{array}{c}-0.196 \\
(0.162)\end{array}$ & $\begin{array}{c}-0.283 \\
(0.215)\end{array}$ & $\begin{array}{l}-0.451 * \\
(0.092)\end{array}$ & $\begin{array}{l}-0.613^{*} \\
(0.062)\end{array}$ & $\begin{array}{l}-0.213^{*} \\
(0.095)\end{array}$ & $\begin{array}{l}-0.043^{* *} \\
(0.023)\end{array}$ & $\begin{array}{l}-0.457^{*} \\
(0.065)\end{array}$ & $\begin{array}{l}-0.029^{* *} \\
(0.031)\end{array}$ \\
\hline МТВ & $\begin{array}{l}0.312^{* *} \\
(0.044)\end{array}$ & $\begin{array}{l}0.049 * * \\
(0.013)\end{array}$ & $\begin{array}{l}0.221 \\
(0.342)\end{array}$ & $\begin{array}{l}0.312 \\
(0.412)\end{array}$ & $\begin{array}{l}0.672 \\
(0.185)\end{array}$ & $\begin{array}{l}0.022 * * \\
(0.033)\end{array}$ & $\begin{array}{l}0.435 \\
(0.185)\end{array}$ & $\begin{array}{l}0.047 * * \\
(0.046)\end{array}$ \\
\hline Tangibility & $\begin{array}{l}0.338^{* * * *} \\
(0.000)\end{array}$ & $\begin{array}{l}0.622^{* *} \\
(0.012)\end{array}$ & $\begin{array}{l}0.551 \\
(0.315)\end{array}$ & $\begin{array}{l}0.297 \\
(0.135)\end{array}$ & $\begin{array}{l}0.236^{* * *} \\
(0.002)\end{array}$ & $\begin{array}{l}0.176^{* *} \\
(0.032)\end{array}$ & $\begin{array}{l}0.332^{* * *} \\
(0.002)\end{array}$ & $\begin{array}{l}0.433^{* * *} \\
(0.004)\end{array}$ \\
\hline NDTS & $\begin{array}{l}-0.233^{* *} \\
(0.021)\end{array}$ & $\begin{array}{c}-0.349 \\
(0.145)\end{array}$ & $\begin{array}{l}-0.732^{* *} \\
(0.029)\end{array}$ & $\begin{array}{l}0.412 \\
(0.129)\end{array}$ & $\begin{array}{l}-0.116^{* * *} \\
(0.000)\end{array}$ & $\begin{array}{l}-0.463^{* *} \\
(0.031)\end{array}$ & $\begin{array}{l}-0.654 * \\
(0.054)\end{array}$ & $\begin{array}{l}-0.543^{* *} \\
(0.022)\end{array}$ \\
\hline Profitability & $\begin{array}{l}-0.481 \\
(0.421)\end{array}$ & $\begin{array}{l}-0.532 \\
(0.348)\end{array}$ & $\begin{array}{l}-0.621 \\
(0.332)\end{array}$ & $\begin{array}{l}-0.432^{*} \\
(0.088)\end{array}$ & $\begin{array}{l}-0.474^{* * *} \\
(0.000)\end{array}$ & $\begin{array}{l}-0.127^{* * *} \\
(0.001)\end{array}$ & $\begin{array}{l}-0.543^{*} \\
(0.067)\end{array}$ & $\begin{array}{l}-0.127^{* * *} \\
(0.031)\end{array}$ \\
\hline Volatility & $\begin{array}{l}0.376 \\
(0.721)\end{array}$ & $\begin{array}{l}0.553 \\
(0.226)\end{array}$ & $\begin{array}{l}0.511 \\
(0.132)\end{array}$ & $\begin{array}{l}0.489 \\
(0.342)\end{array}$ & $\begin{array}{l}0.087 \\
(0.224)\end{array}$ & $\begin{array}{l}0.039 \\
(0.44)\end{array}$ & $\begin{array}{l}0.022 \\
(0.274)\end{array}$ & $\begin{array}{l}0.043 \\
(0.162)\end{array}$ \\
\hline Regulations 2012 & $\begin{array}{l}0.309 \\
(0.221)\end{array}$ & $\begin{array}{l}0.233 \\
(0.399)\end{array}$ & $\begin{array}{l}0.502 \\
(0.188)\end{array}$ & $\begin{array}{l}0.428 \\
(0.221)\end{array}$ & $\begin{array}{l}0.398 \\
(0.409)\end{array}$ & $\begin{array}{l}0.219 \\
(0.189)\end{array}$ & $\begin{array}{l}0.441 \\
(0.220)\end{array}$ & $\begin{array}{l}0.306 \\
(0.161)\end{array}$ \\
\hline Leverage (t-1) & & & & & & & $\begin{array}{l}0.822^{* *} \\
(0.027)\end{array}$ & $\begin{array}{l}0.896^{* * *} \\
(0.000)\end{array}$ \\
\hline R-Sq & 0.44 & 0.59 & 0.54 & 0.37 & 0.33 & 0.37 & & \\
\hline AR (1) test (p-value) & & & & & & & 0.002 & 0.000 \\
\hline AR (2) test (p-value) & & & & & & & 0.182 & 0.442 \\
\hline Hansen-J test (over identification) & & & & & & & 0.253 & 0.678 \\
\hline Diff-in-Hansen test (p-value) & & & & & & & 0.134 & 0.513 \\
\hline Observations & 2592 & 2592 & 2592 & 2592 & 2592 & 2592 & 2592 & 2592 \\
\hline
\end{tabular}

results remained similar in terms of magnitudes and respective signs of the variables of the study. These results corroborate our main findings i.e. a U-shaped non-linear association between CS_Own and leverage decisions and suggesting that family-controlled ownership enhances the negative relationship between controlling ownership and leverage. Therefore, our robustness test regarding variables of interest (leverage, family-controlled firms and Tangibility) are robust to the alternative proxies for the association between controlling shareholders' ownership and leverage.

A potential shortcoming of GMM estimator is instrument proliferation which may bias the estimated coefficients (Amin \& Williamson, 2020; Nguyen et al., 2015). We followed the seminal study of Roodman (2009) regarding the application of GMM approach and test the sensitivity of our results by reducing the numbers of GMM-instruments. We used the 'collapse' option across all GMM estimation to address the problem of instrument proliferation which otherwise may weaken the strength of the GMM instruments (Roodman, 2009; Wintoki, Linck, \& Netter, 2012). ${ }^{3}$ Therefore, in the next line robustness test, we conduct our second sensitivity test by ignoring the 'collapse' option and present the results in Table 11. The results show that $p$-values of explanatory and control variables are slightly changed, but their coefficient signs and level of significance remains the same. For example, the significance level of CS-Own and family-controlled ownership is reduced from $1 \%$ to $10 \%$. The coefficient on the NTDS flip from significant to

\footnotetext{
${ }^{3}$ See Roodman (2009b) for further explanation about the techniques for reducing the instrument count for GMM estimator.
}

insignificance but still shows a negative sign confirming that overall, our findings are robust to model estimation. Taken together, our findings are remained unchanged despite the adjustment in model specification, suggesting that our results are robust to the alternate proxy i.e. reduction in GMM instruments.

\section{Conclusion and discussion}

In this study, we investigate the association between controlling shareholders' ownership and firm leverage decisions in the Singaporean context. We contribute to the literature by examining both the direct impact of control ownership on leverage and the interaction effect of family-controlled firms on the control ownership and leverage relationship. Our core findings reveal that impact of control ownership on leverage financing differs across excess and lower level of control ownership. More specifically, the relationship between excess control and leverage is significantly negative suggesting that controlling shareholders with an excess controlling stake do less rely on leverage financing to minimize the likelihood of financial distress and default risk. Our evidence shows that controlling shareholders of the Singaporean market tend to use leverage financing for an optimal capital structure and focus on value maximisation rather using leverage as a tool of minority shareholders' expropriation. We thus conclude that capital structure decisions in Singapore are linked with the trade-off between the controlling shareholders' target of mitigating firm risk and their non-dilution entrenchment needs. In additions, this outcome is contrary to the prior literature which documents that controlling 
Table 10

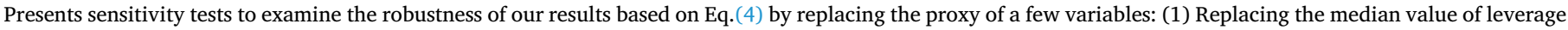

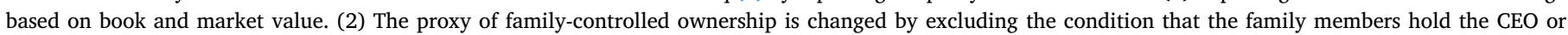

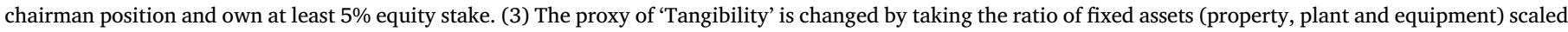
by net assets instead of total Assets.

\begin{tabular}{|c|c|c|c|c|c|c|c|c|}
\hline \multicolumn{5}{|c|}{ Static } & \multicolumn{4}{|l|}{ Dynamic } \\
\hline & \multicolumn{2}{|l|}{ OLS } & \multicolumn{2}{|c|}{ Fixed Effects } & \multicolumn{2}{|l|}{ Fixed Effects } & \multicolumn{2}{|l|}{ GMM } \\
\hline & (1) & (2) & (3) & (4) & (5) & (6) & (7) & (8) \\
\hline CS-Own & $\begin{array}{l}0.023^{* *} \\
(0.041)\end{array}$ & $\begin{array}{l}-0.631 * \\
(0.091)\end{array}$ & $\begin{array}{l}0.031 * \\
(0.082)\end{array}$ & $\begin{array}{l}0.432^{* *} \\
(0.031)\end{array}$ & $\begin{array}{l}0.285^{*} \\
(0.080)\end{array}$ & $\begin{array}{l}0.122^{* * *} \\
(0.000)\end{array}$ & $\begin{array}{l}0.522 * \\
(0.091)\end{array}$ & $\begin{array}{l}0.244^{* * *} \\
(0.004)\end{array}$ \\
\hline CS_Own ${ }^{2}$ & $\begin{array}{l}-0.743^{*} \\
(0.033)\end{array}$ & $\begin{array}{l}-0.322^{* *} \\
(0.021)\end{array}$ & $\begin{array}{l}0.321 * * \\
(0.021)\end{array}$ & $\begin{array}{l}0.232^{*} \\
(0.071)\end{array}$ & $\begin{array}{l}-0.632^{* *} \\
(0.022)\end{array}$ & $\begin{array}{l}-0.131^{* *} \\
(0.012)\end{array}$ & $\begin{array}{l}-0.431^{* *} \\
(0.032)\end{array}$ & $\begin{array}{l}-0.621 * * \\
(0.021)\end{array}$ \\
\hline FCO & $\begin{array}{l}-0.584 * \\
(0.066)\end{array}$ & $\begin{array}{l}-0.532^{*} \\
(0.091)\end{array}$ & $\begin{array}{l}-0.321^{* *} \\
(0.032)\end{array}$ & $\begin{array}{l}-0.241^{* *} \\
(0.043)\end{array}$ & $\begin{array}{l}-0.211^{* * * *} \\
(0.000)\end{array}$ & $\begin{array}{l}-0.212^{* * *} \\
(0.000)\end{array}$ & $\begin{array}{l}-0.432^{* *} \\
(0.021)\end{array}$ & $\begin{array}{l}-0.744^{* *} \\
(0.033)\end{array}$ \\
\hline$(\mathrm{CS}-\mathrm{Own} \times \mathrm{FCO})$ & $\begin{array}{l}-0.921 \\
(0.425)\end{array}$ & $\begin{array}{l}-0.241 \\
(0.161)\end{array}$ & $\begin{array}{l}-0.521 * \\
(0.071)\end{array}$ & $\begin{array}{l}-0.293^{*} \\
(0.091)\end{array}$ & $\begin{array}{l}-0.034^{* * *} \\
(0.000)\end{array}$ & $\begin{array}{l}-0.091 * * * \\
(0.002)\end{array}$ & $\begin{array}{l}-0.052^{* * *} \\
(0.001)\end{array}$ & $\begin{array}{l}-0.031^{* * * *} \\
(0.000)\end{array}$ \\
\hline Firm size & $\begin{array}{l}-0.197^{*} \\
(0.061)\end{array}$ & $\begin{array}{l}-0.282^{* *} \\
(0.014)\end{array}$ & $\begin{array}{l}0.449 \\
(0.692)\end{array}$ & $\begin{array}{l}-0.614^{*} \\
(0.061)\end{array}$ & $\begin{array}{l}-0.212^{*} \\
(0.091)\end{array}$ & $\begin{array}{l}-0.042^{* *} \\
(0.022)\end{array}$ & $\begin{array}{l}-0.422^{*} \\
(0.045)\end{array}$ & $\begin{array}{l}-0.023^{* *} \\
(0.021)\end{array}$ \\
\hline MTB & $\begin{array}{l}0.309^{* *} \\
(0.041)\end{array}$ & $\begin{array}{l}0.042^{* *} \\
(0.012)\end{array}$ & $\begin{array}{l}0.222 \\
(0.341)\end{array}$ & $\begin{array}{l}0.314 \\
(0.411)\end{array}$ & $\begin{array}{l}0.670 \\
(0.184)\end{array}$ & $\begin{array}{l}0.021 * * \\
(0.035)\end{array}$ & $\begin{array}{l}0.434 \\
(0.181)\end{array}$ & $\begin{array}{l}0.044 * * \\
(0.041)\end{array}$ \\
\hline Tangibility & $\begin{array}{l}0.312^{* * *} \\
(0.000)\end{array}$ & $\begin{array}{l}0.621 * * \\
(0.014)\end{array}$ & $\begin{array}{l}0.521 \\
(0.313)\end{array}$ & $\begin{array}{l}0.294 \\
(0.133)\end{array}$ & $\begin{array}{l}0.217^{* * * *} \\
(0.001)\end{array}$ & $\begin{array}{l}0.133^{* *} \\
(0.021)\end{array}$ & $\begin{array}{l}0.322^{* * * *} \\
(0.001)\end{array}$ & $\begin{array}{l}0.455^{* * *} \\
(0.002)\end{array}$ \\
\hline NDTS & $\begin{array}{l}-0.221^{* *} \\
(0.041)\end{array}$ & $\begin{array}{l}0.341 \\
(0.121)\end{array}$ & $\begin{array}{l}-0.721^{* *} \\
(0.021)\end{array}$ & $\begin{array}{l}0.413 \\
(0.124)\end{array}$ & $\begin{array}{l}-0.113^{* * * *} \\
(0.000)\end{array}$ & $\begin{array}{l}-0.643^{* *} \\
(0.022)\end{array}$ & $\begin{array}{l}-0.622 * \\
(0.051)\end{array}$ & $\begin{array}{l}-0.541^{* *} \\
(0.022)\end{array}$ \\
\hline Profitability & $\begin{array}{l}-0.461 \\
(0.429)\end{array}$ & $\begin{array}{c}-0.521 \\
(0.323)\end{array}$ & $\begin{array}{l}0.622 \\
(0.331)\end{array}$ & $\begin{array}{l}-0.433^{*} \\
(0.084)\end{array}$ & $\begin{array}{l}-0.443^{* * *} \\
(0.000)\end{array}$ & $\begin{array}{l}-0.132^{* * *} \\
(0.001)\end{array}$ & $\begin{array}{l}-0.521 * \\
(0.061)\end{array}$ & $\begin{array}{l}-0.121^{* * *} \\
(0.031)\end{array}$ \\
\hline Volatility & $\begin{array}{l}0.371 \\
(0.711)\end{array}$ & $\begin{array}{l}0.536 \\
(0.212)\end{array}$ & $\begin{array}{l}0.512 \\
(0.131)\end{array}$ & $\begin{array}{l}0.481 \\
(0.341)\end{array}$ & $\begin{array}{l}0.081^{* *} \\
(0.021)\end{array}$ & $\begin{array}{l}0.033^{* * *} \\
(0.000)\end{array}$ & $\begin{array}{l}0.021 * \\
(0.071)\end{array}$ & $\begin{array}{l}0.041 * \\
(0.061)\end{array}$ \\
\hline Regulations 2012 & $\begin{array}{l}0.291 \\
(0.221)\end{array}$ & $\begin{array}{l}0.187 \\
(0.381)\end{array}$ & $\begin{array}{l}0.501 \\
(0.452)\end{array}$ & $\begin{array}{l}0.339 \\
(0.321)\end{array}$ & $\begin{array}{l}0.527 \\
(0.122)\end{array}$ & $\begin{array}{l}0.464 \\
(0.319)\end{array}$ & $\begin{array}{l}0.387 \\
(0.461)\end{array}$ & $\begin{array}{l}0.235 \\
(0.234)\end{array}$ \\
\hline Leverage $(\mathrm{t}-1)$ & & & & & & & $\begin{array}{l}0.821^{* *} \\
-0.032\end{array}$ & $\begin{array}{l}0.852^{* * * *} \\
0.061\end{array}$ \\
\hline R-Sq & 0.49 & 0.52 & 0.51 & 0.33 & 0.41 & 0.38 & & \\
\hline AR (1) test (p-value) & & & & & & & 0.001 & 0.000 \\
\hline AR (2) test (p-value) & & & & & & & 0.205 & 0.432 \\
\hline Hansen-J test (over identification) & & & & & & & 0.253 & 0.351 \\
\hline Diff-in-Hansen test (p-value) & & & & & & & 0.143 & 0.520 \\
\hline Observations & 2592 & 2592 & 2592 & 2592 & 2592 & 2592 & 2592 & 2592 \\
\hline
\end{tabular}

P-values are reported in parentheses, whereas, ***; **; * represent significance at the $1 \%, 5 \%$, and $10 \%$ level,respectively.

shareholders prefer higher leverage financing to dilutes the power and authority of minority shareholders (see, for example, Boubaker, 2008; Bianco \& Nicodano, 2006; Faccio \& Lang, 2002; King \& Santor, 2008).

We extend the literature by establishing that the prediction of agency theory is conditional with the weak legal and institutional setting while the Singaporean market is underpinned by the strong institutional and governance arrangements which provide safety against abuse of power. We also argue that from controlling shareholders perspective; the leverage financing is a costly way to influencing corporate policies whilst the excess leverage financing accelerates the risk of financial distress and bankruptcy.

With regard to the estimation of lower control, our analysis shows that the relationship between lower control and leverage is significantly positive. This result suggests that the controlling shareholders with a lower fraction of equity are more concerned about limited holding thus prefers leverage over equity financing to inflate their equity stake to protect them from the potential takeovers and mergers. Further, we argue that firms' capital structure is significantly influenced by the coalition of shareholders particularly decisions about leverage financing in addition to the firms' specific characteristics and institutional arrangements. This is a novel contribution to the capital structure literature as no prior research has elaborated the leverage decisions across excess and lower level of control.

We also examine the impact of the separation of ownership and control on leverage decisions measured using three different wedge scales. Our results show an insignificant relationship between the separation of ownership and control reflecting that controlling shareholders are not extracting private benefit by leverage financing. We report that strong disclosure-based environment and efficient monitoring mechanisms in Singapore effectively protect minority' interests, thus separation of ownership and control has no significant impact on leverage financing. Notably, these findings are in contrast to the classical notion of agency theory whereby separation of ownership and control provide an opportunity for controlling shareholders to pursue their personal incentive which leads to Type II agency problem.

Further, our analysis substantiates an inverted U-shaped (nonmonotonic) association between control ownership and leverage. We report that controlling shareholders first increase the leverage financing to maintain an optimal capital structure reflecting monitoring effect, and at a certain threshold, prefer to reduce the leverage financing indicating the risk reduction/incentive effect. This result is in contrast to the prior study of La Porta et al. (1999) who document that presence of controlling ownership leads to the entrenchment effect particularly in the emerging markets.

We also report a negative interaction effect of family-controlled firms suggesting that family controlling shareholders are more averse towards the higher level of leverage due to the risk of financial distress and bankruptcy and as a result of having poorly and under-diversified leadership portfolio. Given the strong institutional arrangements and higher creditor rights in the Singaporean market, family firms have not the traditional issues such as restricted access to the capital market and lenders' monitoring which is incongruent to the issues of other emerging markets. Further, this result supports the findings of Anderson and Reeb (2003) that family-controlled firms mitigate agency issues with 
Table 11

Presents the second line sensitivity tests to examine the robustness of our results by ignoring the 'collapse' option in GMM estimation.

\begin{tabular}{|c|c|c|c|c|c|c|c|c|}
\hline & \multicolumn{4}{|l|}{ Static } & \multicolumn{4}{|l|}{ Dynamic } \\
\hline & \multicolumn{2}{|l|}{ OLS } & \multicolumn{2}{|c|}{ Fixed Effects } & \multicolumn{2}{|l|}{ Fixed Effects } & \multicolumn{2}{|l|}{ GMM } \\
\hline & (1) & (2) & (3) & (4) & (5) & (6) & (7) & $(8)$ \\
\hline CS-Own & $\begin{array}{l}0.023^{* *} \\
(0.041)\end{array}$ & $\begin{array}{l}-0.631 * \\
(0.091)\end{array}$ & $\begin{array}{l}0.031 * \\
(0.082)\end{array}$ & $\begin{array}{l}0.432^{* *} \\
(0.031)\end{array}$ & $\begin{array}{l}0.285^{*} \\
(0.080)\end{array}$ & $\begin{array}{l}0.122^{* * *} \\
(0.000)\end{array}$ & $\begin{array}{l}0.654^{*} \\
(0.067)\end{array}$ & $\begin{array}{l}0.267^{*} \\
(0.053)\end{array}$ \\
\hline CS_Own ${ }^{2}$ & $\begin{array}{l}-0.743 * \\
(0.033)\end{array}$ & $\begin{array}{l}-0.322^{* *} \\
(0.021)\end{array}$ & $\begin{array}{l}0.321^{* *} \\
(0.021)\end{array}$ & $\begin{array}{l}0.232 * \\
(0.071)\end{array}$ & $\begin{array}{l}-0.632^{* *} \\
(0.022)\end{array}$ & $\begin{array}{l}-0.131^{* *} \\
(0.012)\end{array}$ & $\begin{array}{l}-0.465^{* *} \\
(0.047)\end{array}$ & $\begin{array}{l}-0.666^{* * *} \\
(0.021)\end{array}$ \\
\hline FCO & $\begin{array}{l}-0.584^{*} \\
(0.066)\end{array}$ & $\begin{array}{l}-0.532^{*} \\
(0.091)\end{array}$ & $\begin{array}{l}-0.321^{* *} \\
(0.032)\end{array}$ & $\begin{array}{l}-0.241^{* *} \\
(0.043)\end{array}$ & $\begin{array}{l}-0.211^{* * *} \\
(0.000)\end{array}$ & $\begin{array}{l}-0.212^{* * *} \\
(0.000)\end{array}$ & $\begin{array}{l}-0.467^{*} \\
(0.066)\end{array}$ & $\begin{array}{l}-0.675^{*} \\
(0.071)\end{array}$ \\
\hline$(\mathrm{CS}$-Own $\times$ FCO $)$ & $\begin{array}{l}-0.921 \\
(0.425)\end{array}$ & $\begin{array}{l}-0.241 \\
(0.161)\end{array}$ & $\begin{array}{l}-0.521^{*} \\
(0.071)\end{array}$ & $\begin{array}{l}-0.293^{*} \\
(0.091)\end{array}$ & $\begin{array}{l}-0.034^{* * *} \\
(0.000)\end{array}$ & $\begin{array}{l}-0.091^{* * *} \\
(0.002)\end{array}$ & $\begin{array}{l}-0.054^{* *} \\
(0.043)\end{array}$ & $\begin{array}{l}-0.035^{\text {**** }} \\
(0.002)\end{array}$ \\
\hline Firm size & $\begin{array}{l}-0.197^{*} \\
(0.061)\end{array}$ & $\begin{array}{l}-0.282^{* *} \\
(0.014)\end{array}$ & $\begin{array}{l}0.449 \\
(0.692)\end{array}$ & $\begin{array}{l}-0.614 * \\
(0.061)\end{array}$ & $\begin{array}{l}-0.212^{*} \\
(0.091)\end{array}$ & $\begin{array}{l}-0.042^{* *} \\
(0.022)\end{array}$ & $\begin{array}{l}-0.478 * \\
(0.098)\end{array}$ & $\begin{array}{l}-0.021^{* *} \\
(0.021)\end{array}$ \\
\hline МТВ & $\begin{array}{l}0.309 * * \\
(0.041)\end{array}$ & $\begin{array}{l}0.042^{* *} \\
(0.012)\end{array}$ & $\begin{array}{l}0.222 \\
(0.341)\end{array}$ & $\begin{array}{l}0.314 \\
(0.411)\end{array}$ & $\begin{array}{l}0.670 \\
(0.184)\end{array}$ & $\begin{array}{l}0.021^{* *} \\
(0.035)\end{array}$ & $\begin{array}{l}0.436 \\
(0.187)\end{array}$ & $\begin{array}{l}0.032^{* *} \\
(0.055)\end{array}$ \\
\hline Tangibility & $\begin{array}{l}0.312^{* * * *} \\
(0.000)\end{array}$ & $\begin{array}{l}0.621 * * \\
(0.014)\end{array}$ & $\begin{array}{l}0.521 \\
(0.313)\end{array}$ & $\begin{array}{l}0.294 \\
(0.133)\end{array}$ & $\begin{array}{l}0.217^{* * *} \\
(0.001)\end{array}$ & $\begin{array}{l}0.133^{* *} \\
(0.021)\end{array}$ & $\begin{array}{l}0.316^{*} \\
(0.093)\end{array}$ & $\begin{array}{l}0.467^{* *} \\
(0.032)\end{array}$ \\
\hline NDTS & $\begin{array}{l}-0.221^{* *} \\
(0.041)\end{array}$ & $\begin{array}{l}0.341 \\
(0.121)\end{array}$ & $\begin{array}{l}-0.721^{* *} \\
(0.021)\end{array}$ & $\begin{array}{l}0.413 \\
(0.124)\end{array}$ & $\begin{array}{l}-0.113^{* * *} \\
(0.000)\end{array}$ & $\begin{array}{l}-0.643^{* *} \\
(0.022)\end{array}$ & $\begin{array}{c}-0.676 \\
(0.172)\end{array}$ & $\begin{array}{l}-0.535 \\
(0.321)\end{array}$ \\
\hline Profitability & $\begin{array}{l}-0.461 \\
(0.429)\end{array}$ & $\begin{array}{l}-0.521 \\
(0.323)\end{array}$ & $\begin{array}{l}0.622 \\
(0.331)\end{array}$ & $\begin{array}{l}-0.433^{*} \\
(0.084)\end{array}$ & $\begin{array}{l}-0.443^{* * *} \\
(0.000)\end{array}$ & $\begin{array}{l}-0.132^{* * *} \\
(0.001)\end{array}$ & $\begin{array}{l}-0.533^{*} \\
(0.061)\end{array}$ & $\begin{array}{l}-0.156^{* * *} \\
(0.045)\end{array}$ \\
\hline Volatility & $\begin{array}{l}0.371 \\
(0.711)\end{array}$ & $\begin{array}{l}0.536 \\
(0.212)\end{array}$ & $\begin{array}{l}0.512 \\
(0.131)\end{array}$ & $\begin{array}{l}0.481 \\
(0.341)\end{array}$ & $\begin{array}{l}0.081^{* *} \\
(0.021)\end{array}$ & $\begin{array}{l}0.033^{* * *} \\
(0.000)\end{array}$ & $\begin{array}{l}0.046^{*} \\
(0.070)\end{array}$ & $\begin{array}{l}0.041 * \\
(0.061)\end{array}$ \\
\hline Regulations 2012 & $\begin{array}{l}0.291 \\
(0.221)\end{array}$ & $\begin{array}{l}0.187 \\
(0.381)\end{array}$ & $\begin{array}{l}0.501 \\
(0.452)\end{array}$ & $\begin{array}{l}0.339 \\
(0.321)\end{array}$ & $\begin{array}{l}0.527 \\
(0.122)\end{array}$ & $\begin{array}{l}0.464 \\
(0.319)\end{array}$ & $\begin{array}{l}0.452 \\
(0.221)\end{array}$ & $\begin{array}{l}0.290 \\
(0.141)\end{array}$ \\
\hline Leverage (t-1) & & & & & & & $\begin{array}{l}0.862 * * \\
(0.027)\end{array}$ & $\begin{array}{l}0.842^{* * *} \\
(0.066)\end{array}$ \\
\hline R-Sq & 0.49 & 0.52 & 0.51 & 0.33 & 0.41 & 0.38 & & \\
\hline AR (1) test (p-value) & & & & & & & 0.001 & 0.000 \\
\hline AR $(2)$ test (p-value) & & & & & & & 0.272 & 0.329 \\
\hline Hansen-J test (over identification) & & & & & & & 0.182 & 0.527 \\
\hline Diff-in-Hansen test (p-value) & & & & & & & 0.177 & 0.484 \\
\hline Observations & 2592 & 2592 & 2592 & 2592 & 2592 & 2592 & 2592 & 2592 \\
\hline
\end{tabular}

P-values are reported in parentheses, whereas, ***; **; * represent significance at the $1 \%, 5 \%$, and $10 \%$ level,respectively.

the debt holders which reduce the cost of leverage financing. To our knowledge, the present study is the first to explore the family ownership in the Singaporean context and determine its moderating impact on controlling shareholders and leverage relationship.

In addition, we perform two independent robustness tests reflecting that our results are robust to the alternative proxies for the association between controlling shareholders' ownership and firm leverage. In terms of implications of this study, our empirical evidence shows that the shareholders with a lower controlling stake in Singapore prefer leverage over equity financing to inflate their equity stake. This reflects that regardless of disclosure-based environment and governance arrangements in Singapore, minority shareholders are not fully protected thus concerned about their limited holding. Given that the present study emphasis on leverage financing, we suggest that future studies can obtain the firms' equity data to look into issues related to optimal capital structure with the comparison of leverage financing. We acknowledge a few limitations of this research. First, we exclude the nonlisted firms which plays an important role in economic development. Second, we also exclude GLCs in our model estimation due to the difference in ownership structure.

\section{References}

Abdullah, N., \& Pok, C. W. (2015). Separation of cash flow rights and control rights and debt among Malaysian family firms. Journal of Accounting in Emerging Economies, 5(2), 184-201.

Abor, J. (2008). Determinants of the capital structure of Ghanaian Firms. African Economic Research Consortium. http://dspace.africaportal.org/jspui/bitstream/ 123456789/32100/1/RP176.pdf?1.

Agca, S., \& Mansi, S. (2008). Managerial ownership, takeover defences, and debt financing. Journal of Finance, 31(2), 85-112.
Agyei-Boapeah, H. (2015). Cross-border acquisitions and financial leverage of UK acquirers. Accounting Forum, 39, 97-108.

Amin, Q. A., \& Williamson, T. (2020). Cash management, adjustment cost and its impact on firms' speed of adjustment: a cross country analysis. Review of Quantitative Finance and Accounting, 54 70-92.

Anderson, R. C., \& Reeb, D. M. (2003). Founding-family ownership, corporate diversification, and firm leverage. Journal of Law and Economics, 46(2), 653-684.

Antoniou, A., Guney, Y., \& Paudyal, K. (2008). The determinants of capital structure; Capital market oriented versus bank-oriented institutions. Journal of Financial and Quantitative Analysis, 43(1), 59-92.

Arslan-A, O., Karan, B., \& M. (2006). Ownership and control structures as determinants of corporate debt maturity: A panel study of an emerging market. Corporate Governance: An International Review, 14(4), 312-324.

Barth, E., Gulbrandsen, T., \& Schonea, P. (2005). Family ownership and productivity: The role of owner-management. Journal of Corporate Finance, 11(1-2), 107-127.

Bauer, R., Frijns, B., Otten, R., \& Tourani-Rad, A. (2008). The impact of corporate governance on corporate performance: Evidence from Japan. Pacific Basin Finance Journal, 16(3), 236-251.

Berger, P. G., Ofek, E., \& Yermack, D. L. (1997). Managerial entrenchment and capital structure decisions. The Journal of Finance, 52, 1411-1438.

Bianco, M., Bontempi, M. E., Golinelli, R., \& Parigi, G. (2013). Family firms' investments, uncertainty and opacity. Small Business Economics, 40, 1035-1058.

Bianco, M., \& Nicodano, G. (2006). Pyramidal groups and debt. European Economic Review, 50, 937-961.

Boateng, A., \& Huang, W. (2017). Multiple large shareholders, excess leverage and Tunnelling: Evidence from an emerging market. Corporate Governance: An International Review, 25(1), 58-74.

Boubaker, S. (2008). On the relationship between ownership-control structure and debt financing: New evidence from France. Corporate Ownership \& Control, 5(1), 139-154.

Boubakri, N., \& Ghouma, H. (2010). Control/ownership struc-ture, creditor rights protection, and the cost of debt financing: international evidence. Journal of Banking \& Finance, 34, 2481-2499.

Brailsford, T. J., Oliver, B. R., \& Pua, S. L. (2002). On the relation between ownership structure and capital structure. Accounting and Finance, 42(1), 1-26.

Casado, R. B., Burkert, M., Davila, A., \& Oyon, D. (2016). Shareholder protection: The role of multiple large shareholders. Corporate Governance: An International Review, 24(2), 105-129.

Chee, H. K., Hooy, C.-W., \& Ooi, C.-A. (2016). The influence of ultimate ownership 
concentration on leverage. Journal Pengurusan, 4755-4765.

Chuanrommanee, W., \& Swierczek, F. W. (2007). Corporate governance in ASEAN financial corporations: Reality or illusion. Corporate Governance, 15(2), 272-283.

Claessens, S., Djankov, S., Fan, J., \& Lang, L. (2002). Disentangling the incentive and entrenchment effects of large shareholdings. Journal of Finance, 57, 2741-2771.

Claessens, S., Djankov, S., \& Lang, L. H. (2000). The separation of ownership and control in east Asian corporations. Journal of Financial Economics, 58(1-2), 81-112.

CLSA (2010). Corporate governance watch. Hong Kong: Credit Lyonnais Securities Asia.

CLSA (2012). Corporate governance watch. Hong Kong: Credit Lyonnais Securities Asia.

Croci, E., Doukas, J. A., \& Gonenc, H. (2011). Family control and financing decisions. European Financial Management, 17(5), 860-897.

Cronqvist, H., \& Nilsson, M. (2003). Agency costs of controlling minority shareholders. Journal of Financial and Quantitative Analysis, 38(4), 695-719.

Crutchley, C. E., Jensen, M. H., Jahera, J. S., Jr., \& Raymond, J. E. (1999). Agency problems and the simultaneity of financial decisions making: The role of institutional ownership. International Review of Financial Analysis, 8(2), 177-197.

De Jong, A., Rezaul, K., \& Nguyen, T. T. (2008). Capital structure around the world: The roles of firm-and country-specific determinants. Journal of Banking \& Finance, 32(9), 1954-1969.

De Miguel, A., Pindado, J., \& De la Torre, C. (2004). Ownership structure and firm value: New evidence from Spain. Strategic Management Journal, 25, 1199-1207.

de La Bruslerie, H., \& Latrous, I. (2012). Ownership structure and debt leverage: Empirical test of a trade-off hypothesis on French firms. Journal of Multinational Financial Management, 22, 111-130.

Demirbag, Mehmet, \& Yaprak, Attila (2015). Conclusions and future research directions : lessons learned from the rise of emerging-market multinationals. In Mehmet Demirbag, \& Attila Yaprak (Eds.). Handbook of Emerging Market Multinational Corporations (pp. 260-270). Cheltenham: Edward Elgar (ISBN 9781782544999).

Du, J., \& Dai, Y. (2005). Ultimate corporate ownership structures and capital structures: Evidence from east Asian economies. Corporate Governance: International review, 13(1), 60-71.

Hasso, T., \& Duncan, K. (2013). Valuation of family firms: The limitations of accounting information. Australian Accounting Review, 23(2), 135-150.

Dyck, A., \& Zingales, L. (2004). Private benefits of control: An international comparison. The Journal of Finance, 59(2), 537-600.

Faccio, M., \& Lang, L. H. P. (2002). The ultimate ownership of Western European corporations. Journal of Financial Economics, 65, 365-395.

Gama, A. P. M., \& Galvão, J. M. M. (2012). Performance, valuation and capital structure: Survey of family firms. Corporate Governance: The International Journal of Business in Society, 12, 199-214.

Hanazaki, M., \& Liu, Q. (2007). Corporate governance and investment in east Asian firms' empirical analysis of family-controlled firms. Journal of Asian Economics, 18(1), 76-97.

Harris, M., \& Raviv, A. (1988). Corporate control contests and capital structure. Journal of Financial Economics, 20, 55-86.

Hermalin, B. E., \& Weisbach, M. S. (1991). The effects of board composition and direct incentives on firm performance. Financial Management, 20, 101-112.

Heugens, P. P. M. A. R., Van Essen, M., \& Van Oosterhout, J. (2009). Meta-analyzing ownership concentration and firm performance in Asia: Towards a more fine-grained understanding. Asia Pacific Journal of Management, 26(3), 481-512.

Hiebl, M. R. (2012). Risk aversion in family firms: What do we really know? The Journal of Risk Finance, 14, 49-70.

Jensen, G. R., Solberg, D. P., \& Zorn, T. S. (1992). Simultaneous determination of insider ownership, debt and dividend policies. The Journal of Financial and Quantitative Analysis, 27(2), 247-263.

Jensen, M. C. (1986). Agency cost of free cash flow, corporate finance, and takeovers. The American Economic Review, 76(2), 323-329.

Jensen, M. C., \& Meckling, W. H. (1976). Theory of the firm: Managerial behaviour, agency costs, and ownership structure. Journal of Financial Economics, 3, 305-360.

King, M. R., \& Santor, E. (2008). Family values: Ownership structure, performance and capital structure of Canadian firms. Journal of Banking \& Finance, 32(11), 2423-2432.

de La Bruslerie, H., \& Latrous, I. (2012). Ownership structure and debt leverage: Empirical test of a trade-off hypothesis on French firms. Journal of Multinational Financial Management, 22, 111-130.

La Porta, R., Lopez-de-Silanes, F., \& Shleifer, A. (1999). Corporate ownership around the world. Journal of Finance, 54, 471-517.

Lee, C. F., \& Kuo, N. T. (2014). Effects of ultimate ownership structure and corporate tax on capital structures: Evidence from Taiwan. International Review of Economics and Finance, 29(C), 409-425.

Lemmon, M. L., \& Lins, K. (2003). Ownership structure, corporate governance, and firm value: Evidence from the East Asian Financial. The Journal of Finance. L.VIII (4).

Li, K., Lu, L., Mittoo, U. R., \& Zhang, Z. (2015). Board independence, ownership concentration: Chinese evidence. International Review of Financial Analysis, 41(C), 162-175.

Lo, HC.,Ting, IWK.,Kweh,QL.,Yang, MJ. (2016). Nonlinear association between ownership concentration and leverage: The role of family control. International Review of Financial Analysis, 46,113-123.

Lundstrum, L. L. (2009). Entrenched management, capital structure changes and firm value. Journal of Economics and Finance, 33(2), 161-175.

Margaritis, D., \& Psillaki, M. (2010). Capital structure, equity ownership and firm performance. Journal of Banking \& Finance, 34(3), 621-632.

Maury, B., \& Pajuste, A. (2002). Controlling shareholders, agency problems and dividend policy in Finland. Financial Journal of Business Economics, 1(2), 15-45.

Mishra, C. S., \& McConaughy, D. L. (1999). Founding family control and capital structure: The risk of loss of control and the aversion to debt. Entrepreneurship: Theory and Practice, 23(4), 53-64.

Modigliani, F., \& Miller, M. (1958). The cost of capital, corporation finance and the theory of investment. American Economic Review, 48, 261-297.

Myers, S. C., \& Majluf, N. S. (1984). Corporate financing and investment decisions when firms have information that investors do not have. Journal of Financial Economics, 13, 187-221. https://doi.org/10.1016/0304-405X(84)90023-0.

Nenova, T. (2003). The value of corporate voting rights and control: A cross-country analysis. Journal of Financial Economics, 68, 325-351.

Nguyen, T., Locke, S., \& Reddy, K. (2015). Ownership concentration and corporate performance from a dynamic perspective: Does national governance quality matter. International Review of Financial Analysis, 41, 148-161.

Nielsen, A. (2006). Corporate governance, leverage and dividend policy. EFA Zurich Meeting www.ssrn.com.

Paligorova, T., \& Xu, Z. (2012). Complex ownership and capital structure. Journal of Corporate Finance, 18, 701-716.

Rajan, R. G., \& Zingales, L. (1995). What do we know about capital structure? Some evidence from international data. Journal of Finance, 50, 1421-1460.

Roodman, D. (2009). How to do xtabond2: an introduction to difference and systemGMM in Stata. The Stata Journal, 9(1), 86-136.

Ross, S. (1977). The Determination of Financial Structure: The Incentive-Signalling Approach. Bell Journal of Economics, 8(1), 23-40.

Santos, M. S., Moreira, A. C., \& Vieira, E. S. (2014). Ownership concentration, contestability, family firms, and capital structure. Journal of Management and Governance, 18(4), 1063-1107.

Ampenberger, M., Schmid, T., Achleitner, A. K., \& Kaserer, C. (2011). Capital structure decisions in family firms: Empirical evidence from a bank-based economy. Review of Managerial Science, 7(3), 247-275.

Schultz, E. L., Tan, D. T., \& Walsh, K. D. (2010). Endogeneity and the corporate governance-performance relation. Australian Journal of Management, 35(2), 145-163.

Setia-Atmaja, L. (2010). Dividend and debt policies of family controlled firms: The impact of board independence. International Journal of Managerial Finance, 6, 128-142.

Setia-Atmaja, L., Tanewski, G. A., \& Skully, M. (2009). The role of dividends, debt, and board structure in the governance of family controlled firms. Journal of Business Finance and Accounting, 36, 863-898.

Sogorb-Mira, F. (2005). How SME uniqueness affects capital structure: Evidence from a 1994-1998 Spanish data panel. Small Business Economics, 25(5), 447-457.

Stulz, R. (1988). Managerial control of voting rights: Financing policies and the market for corporate control. Journal of Finance and Economics, 20, 25-64.

Wintoki, M. B., Linck, J. S., \& Netter, J. M. (2012). Endogeneity and the dynamics of internal corporate governance. Journal of Financial Economics, 105, 581-606.

Witt, M. A. (2012). Global perspectives on corporate governance and initial public offerings in Singapore. In A. Zattoni, \& W. Judge (Eds.). Global perspectives on corporate governance and initial public offerings. Cambridge, UK: Cambridge University Press.

Wiwattanakantang, Y. (1999). An empirical study on the determinants of the capital structure of Thai firms. Pacific-Basin Finance Journal, 7(3-4), 371-403.

World Bank. (2013). Doing business. Smarter regulations for small and medium-size enterprises-economy profile: Singapore. Washington DC., USA: The World Bank.

Yusuf, F., Yousaf, A., \& Saeed, A. (2018). Rethinking agency theory in developing countries: A case study of Pakistan. Accounting Forum, 42, 281-292. 